Review Article

\title{
Plant Growth Promoting Rhizobacteria (PGPR): A Novel Agent for Sustainable Food Production
}

\author{
Odoh Chuks Kenneth, Eze Chibuzor Nwadibe, Akpi Uchenna Kalu and Unah Victor Unah \\ Department of Microbiology, University of Nigeria, Nsukka, 410001, Enugu, Nigeria
}

\author{
Article history \\ Received: 12-11-2017 \\ Revised: $14-03-2018$ \\ Accepted: 19-04-2018 \\ Corresponding Author: \\ Odoh Chuks Kenneth \\ Department of Microbiology, \\ University of Nigeria, Nsukka, \\ 410001, Enugu, Nigeria \\ Tel: +2347032160674 \\ Email: kenchuks974@gmail.com
}

\begin{abstract}
Plant Growth Promoting Rhizobacteria (PGPR) involves the use of large array of soil bacteria to improve yield, plant growth and sustainable food production. As free living and symbiotic rhizobacteria, PGPR exert its role by colonizing extracellular and/or intracellular rhizoenvironment in the quest for carbon source. In the past decades, focus has been on developing a biosafety agro base approach void of continuous burden on soil micro flora as a result of agrochemicals application. However, with clear understanding of PGPR mechanisms of action "biocontrol, biofertilization and biostimulation", more hope on the possibility of curbing food insecurity amidst rising population has been strengthened. Seeds or soil application of PGPR inoculants enhances phosphates solubilization, biological nitrogen fixation and secretion of plant hormones (indole acetic acid, gibberellins, cytokinins and ethylene) needed for growth and adaptation in stressed environment. As soil pathogen constantly rival the roles of these organisms, PGPR has developed over time wide spectrum of strategies in the form of systemic resistance, iron, space and nutrient competition, antibiotics synthesis, lytic acid production and hydrogen cyanide for efficient food production. In view of this, the review broadens our scope on the use of PGPR as an efficient microbial consortium for enhanced agrobiology and sustenance especially in the tropics were paucity of data on its use, implementation and application of genetically modified organisms has long prevailed.
\end{abstract}

Keywords: Plant Growth Promoting Rhizobacteria (PGPR), Biofertilization, Biostimulation, Biocontrol, Sustainable Food Production

\section{Introduction}

The word "sustainable food production" has been an echoing phrase among policy makers, relevant national agencies and international organizations over the past decades. This has become ultimately one of the world most fundamental need to curb food insecurity amidst rising human population (Glick, 2012). Within the last century, man has gradually been faced with the greatest challenge of all time (food insecurity), which has potential of possible looming consequences on the entire human race. Overcoming this confront also will not be an easy task as there has been so much pressure on the natural ecosystem (use of plant for bioethanol) (Chatzipavlidis et al., 2013).

Agriculture has remained the main stream of economic activities within the third world, most importantly in Sub-Sahara Africa. The emergence of mechanized/industrialized agricultural activities has continuously welcomed pollutants in the form of fossil fuel used in powering plants, agro-chemicals, contaminated sewage sludge during irrigation and excessive application of fertilizers. These practices do not only leave an indelible mark on the soil environment but also alters microbial population which aid in plant growth. The use of synthesized agro chemicals/fertilizer has been a point of discuss in public domain in the time past. Though their advantages tend to be immediate, they still present a lasting environmental and public health threat to man through possible entrance of heavy metals via the food chain, death of soil biotic life, environmental deterioration and degradation and alteration or damage of soil structure (Alalaoui, 2007).

Since the inception of microbiological research, only about $1 \%$ of the estimated amount of microorganisms has so far been identified. This has left us with large array of microbes that their existence can only be 
imagined. These documented organisms live in complex biological environment within which exist interactions arising from other living and non-living influences (Petersen and Klug, 1994). To combat food insecurity through agrobiology, there is need to pay stern attention on the engineering of beneficial microorganisms resident in the soil that has been ascribed with potentials of mitigating associated difficulties in agricultural practices. Thus, suggesting their utilization in environmental cleanup (Van-Veen et al., 1997), renewable energy (Jackson, 1992) and attainment of sustainable agricultural activities (Noumavo et al., 2016).

\section{Rhizosphere}

The word rhizosphere is referred to the immediate plant root region inhabited by microbial population. This region is host to divers group of microorganisms that are influenced by rich source of nutrients obtain through the root exudates. The subdivision of this rhizosphere into three separate parts 'exorhizosphere, rhizoplane, endorhizosphere' was reported by Bowen and Rovira (1999). These regions support healthy competition among organisms for more competency, saprophytic abilities and potential for enhancing plants growth. In addition, its successful organism multiply easily through a broad spectrum of actions as a result of high nutrient and carbon source, favourable competition with other organisms and poses tolerance to stress (Nakkeeran et al., 2005; Ngumbi and Kloepper, 2016). Since rhizosphere is very rich in nutrients, its associate bacteria (rhizobacteria) tend to develop a unique way of communication by enabling of effective selection of its mutual partners, through the creation of host specificity and selective sensitive environment where diversity is less (Sivasakthi et al., 2014).

\section{Rhizobacteria and Microflora of the Bulk Soil}

Bacteria fund over $95 \%$ of the soil microbial activities and are also dominant in abundant. This is as a result of their fast proliferation and ability to utilize a range of nitrogen and carbon source as energy (Glick, 2012). The rhizobacteria concentration in the rhizosphere is estimated to be $10^{12} \mathrm{CFU} / \mathrm{g}$ (Foster, 1988) while rhizospheric flora which occurs few distance around the root region contains fairly large amount of microbial population $10^{8}-10^{9} \mathrm{CFU} / \mathrm{g}$ (Schoenborn et al., 2004; Compant et al., 2010). Under intense environmental stress, rhizobacteria population in the soil ecosystem might be drastically reduced to $10^{4} \mathrm{CFU} / \mathrm{g}$ (Timmusk et al., 2011). Microbial structure of the bulk soil flora and rhizobacteria differs with the plant developmental stage, specie type and soil property (Broeckling et al., 2008). Some of the interactions that occur within the rhizosphere and the rhizospheric bulk soil can be said to be neutral, synergistic or antagonistic. The participating genera involved in harmful interaction tend to work against the plant growth, exerting effects in the form of phytopathogen while the beneficial once enhances growth with ability to support nutritional provision (Mahdi et al., 2010; Ahemad and Khan, 2011).

\section{Plant Growth Promoting Rhizobacteria (PGPR)}

PGPR was first proposed by Kloepper et al. (1980) when he utilized Fluorescent Pseudomonas as growth enhancer capable of withstanding plant pathogens. Since then, the term has metamorphosed to include all rhizobacteria capable of directly enhancing plants growth. Recently, it has been used to include wide range of rhizobacteria (Alcaligenes, Pseudomonas, Azospirillum, Bacillus, Klebsiella, Azotobacter, Enterobacter, Burkholderia, Arthrobacter and Serratia) that improves plant growth through different mechanisms (Saharan and Nehra, 2011; Haghighi et al., 2011) (Table 1). PGPR exhibit a special role by hindering plant infestation with disease, increase nutrient absorption, enhance root and shoot formation, improve seed germination and making the plant more tolerant to most environmental stress (Arora et al., 2008; Lugtenberg and Kamilova, 2009). Interestingly, these organisms have been accrued with fascinating roles ranging from enhanced nitrogen fixation through nodule formation, solubilization of phosphates, production of phytohormones such gibberellins, siderophores, indole acetic acid and serving as low molecular weight agents that modulate plant growth and development (Ma et al., 2009; Odoh, 2017).

\section{PGPR in Agriculture}

Agriculture is an age long practice. It's involves the tilling of land and rearing of livestock for food and economic growth. These practices are considered to be the most important human occupation within the tropics (Khan et al., 2014b). Rhizobacteria through the improvement of plant growth, synthesizes some secondary metabolites such as phytohormone, enzymes, siderophores and antibiotics (Noordman et al., 2006; Ahmad et al., 2008), required for plant growth. They help in fixing atmospheric nitrogen, provide nutritional uptake by solubilizing phosphate and producing biologically active molecules (Arshad and Frankenberger, 1992). Studies has shown that for PGPR to be utilized in crop production, it must be able to exert its effects in either one of these three ways; providing the plant with growth-promoting compounds (Glick, 1995), uptake of certain essential nutrients such as phosphorus, nitrogen, sulfur, calcium and magnesium, (Cakmakci et al., 2006; Belimov and Dietz 2000) and averting plants diseases (Khan et al., 2002; Lugtenberg and Kamilova, 2009). 
Table 1: Plant growth promoting rhizobacteria, its mode of action and possible outcome

\begin{tabular}{|c|c|c|c|c|}
\hline PGPR & Mode of action & Plants & Outcome & References \\
\hline Achromobacter & $\begin{array}{l}\text { Indole acetic acid } \\
\text { synthesis and Phosphate } \\
\text { solubilization }\end{array}$ & & Improves all round growth performance & Ma et al. (2009) \\
\hline Azoarcus & Nitrogen fixation & Rice & $\begin{array}{l}\text { In situ gradual spread and dominant of } \\
\text { inoculants over the plant endophytic } \\
\text { life style. }\end{array}$ & $\begin{array}{l}\text { Reinhold-Hurek and } \\
\text { Hurek (1998) }\end{array}$ \\
\hline Azorhizobium & Nitrogen fixation & Wheat & $\begin{array}{l}\text { Increased lateral root formation and } \\
\text { development }\end{array}$ & Sabry et al. (1997) \\
\hline Azotobacter & Nitrogen fixation & $\begin{array}{l}\text { Wheat, Tobacco, } \\
\text { Maize, Coffee }\end{array}$ & & Wani et al. (2013) \\
\hline Bacillus & Antibiotic production & Alfafa & $\begin{array}{l}\text { After inoculation on the seedlings } \\
\text { Bacillus cultures suppresses alfalfa } \\
\text { disease causing agent } P \text {. medicaginis }\end{array}$ & Silo-Suh et al. (1994) \\
\hline Bacillus & Auxin synthesis & Potato & $\begin{array}{l}\text { The strain enhances the auxin content } \\
\text { of the inoculated plants at more than } \\
400 \% \text { when compared to the } \\
\text { non-inoculated once. }\end{array}$ & \\
\hline Bacillus & Cytokinin synthesis & Cucumber & Well-developed lateral roots. & Sokolova et al. (2011) \\
\hline Bacillus & Gibberellin synthesis & & Peper & Joo et al. (2005) \\
\hline Bacillus & $\begin{array}{l}\text { Induction of plants } \\
\text { stress and resistance }\end{array}$ & Peanuts & $\begin{array}{l}\text { Plant becomes more stress tolerance due } \\
\text { to increased soil N, P and K content } \\
\text { arising from the inoculants. They also } \\
\text { serve as alternative to chemical fertilizer. }\end{array}$ & El-Akhal et al., 2013 \\
\hline $\begin{array}{l}\text { Brevibacillus } \\
\text { Brevis }\end{array}$ & $\begin{array}{l}\text { Indole acetic acid } \\
\text { synthesis }\end{array}$ & & $\begin{array}{l}\text { Efficient in plants and micorrhizal } \\
\text { growth even at high metal toxicity }\end{array}$ & Vivas et al. (2006) \\
\hline Chryseobacterium & Siderophore production & Tomato & $\begin{array}{l}\text { Increase soil microbial biomass } \\
\text { vis-à-vis soil nutrient. }\end{array}$ & Radzki et al. (2013) \\
\hline Frankia & Nitrogen fixation & Alnus & & Simonet et al. (1990) \\
\hline Gluconacetobacter & Nitrogen fixation & Sugar cane & & $\begin{array}{l}\text { Muñoz-Rojas and } \\
\text { Caballero-Mellado (2003) }\end{array}$ \\
\hline Kluyvera ascorbata & Siderophore production & & & Burd et al. (2000) \\
\hline $\begin{array}{l}\text { Microbacterium } \\
\text { G16 }\end{array}$ & $\begin{array}{l}\text { Indole acetic acid } \\
\text { synthesis and } \\
\text { siderophores production } \\
\text { Rape (Brassica napus) }\end{array}$ & & & Sheng et al. (2008) \\
\hline $\begin{array}{l}\text { Micrococcu } \\
\text { luteus, } \\
\text { Rhizobium, } \\
\text { Bradyrhizobioum }\end{array}$ & $\begin{array}{l}\text { Indole acetic acid } \\
\text { synthesis and Phosphate } \\
\text { solubilization }\end{array}$ & Non-legumes & & Antoun et al. (2004) \\
\hline Mycobacterium & $\begin{array}{l}\text { Induction of plants } \\
\text { stress resistance }\end{array}$ & Maize & & Egamberdiyeva (2007) \\
\hline Peanibacillus & $\begin{array}{l}\text { Indole acetic acid } \\
\text { synthesis }\end{array}$ & Lodgepole pine & & Bent et al. (2001) \\
\hline Phyllobacterium & $\begin{array}{l}\text { Potassium and phosphate } \\
\text { solubilization }\end{array}$ & Strawberries & $\begin{array}{l}\text { Aid in phosphate solubilization and } \\
\text { plants protection against pathogens }\end{array}$ & Flores-Felix et al. (2015) \\
\hline Pseudomonas & Antibiotics production & Wheat & & Mazzola et al. (1995) \\
\hline Pseudomonas & ACC deaminase synthesis & Mung bean & & Ahmad et al. (2013) \\
\hline Rhizobia & Nitrogen fixation & Legume & & $\begin{array}{l}\text { Young and Haukka } \\
\text { (1996) }\end{array}$ \\
\hline Rhizobia & Hydrogen cyanide & Legume & & Thamer et al. (2011) \\
\hline Rhizobium & $\begin{array}{l}\text { Indole acetic acid } \\
\text { synthesis }\end{array}$ & Lettuce & $\begin{array}{l}\text { Increase plants biomass due to enhanced } \\
\text { nutrient uptake }\end{array}$ & Flores-Felix et al. (2013) \\
\hline Rhizobium & Siderophore production & Peper, carot & $\begin{array}{l}\text { Serves as a protective shield against } \\
\text { plants disease }\end{array}$ & Garcia-Fraile et al. (2012) \\
\hline Streptomyces & Siderophore production & Indian lilac & & Verma et al. (2011) \\
\hline Sphingomonas & Gibberelin synthesis & Tomato & & Khan et al. (2014a) \\
\hline Sinorhizobium & $\begin{array}{l}\text { Chitanase and glucanas } \\
\text { production }\end{array}$ & Pigeon pea & & Kumar et al. (2010) \\
\hline
\end{tabular}

Evident of these are demonsted in the improved growth and productivity of many commercial crops such as maize (Sandhya et al., 2010), rice (Ashrafuzzaman et al., 2009), black pepper (Dastager et al., 2010), wheat (Cakmakci et al., 2007), sugarcane (Sundara et al., 2002), cotton (Anjum et al., 2007),
Banana (Mia et al., 2010) and cucumber (Maleki et al., 2010). There has been public call for possible exploitation of PGPR in biofertilizers production, microbial rhizoremediation (Odoh et al., 2017a) and biopesticides synthesis (Adesemoye et al., 2008) for sustainable environment. 


\section{Mechanisms of Action}

In recent time, PGPR has been classified based on its direct ability to provide essential compound to plants or indirectly by preventing the deleterious effects of phytopathogenic organisms (Glick, 1995). The direct mechanisms include biofertilization, stimulation of root growth, rhizo-remediation, phytohormones production, plant stress control and efficient uptake of certain nutrients from the environment. Besides reduction of plants disease through antibiotic production, antifungal metabolites, induction of systemic resistance; they also compete favorably with pathogen for nutrients and niches (Pliego et al., 2011; Egamberdieva and Lugtenberg, 2014). In general, PGPR function by preventing plants diseases condition "Biocontrol", facilitating the uptake of certain nutrients from the environment "Biofertilization" and synthesizing phytohormones "Biostimulants" (Glick et al., 1998). Advances in these field has implicated PGPR in growth promotion of soil stabilizing plants, control flooding, aid plant growth in acidic conditions, and used in phytoremediation technologies (Burd et al., 2000; Zhuang et al., 2007; Odoh et al., 2017b).

\section{Biocontrol}

PGPR has been identified as biocontrol agent with the capacity to suppress a wide range of organisms possible of presenting disease condition in plant. For rhizobacterial to be an efficient biocontrol agent against pathogenic bacteria, fungi and viruses, it must utilize one of the following mechanisms; production of antibiotics, competition for nutrients and niche, signal interference, induced systemic resistance, hydrogen cyanide and lytic enzymes production (Podile and Kishore, 2006; Lugtenberg and Kamilova, 2009). Generally, these mode of actions antagonizes fungi, bacteria and nematode as pathogens of interest in their order of severity. Consequently, PGPR control the involvement and application of beneficial rhizobacteria or their metabolites in minimizing the negative impact of pathogens while promoting healthy living in plants (Junaid et al., 2013).

\section{Biocontrol Mode of Actions}

The preferential rate of spore-forming Bacillus and other specie by farmers who are recognizing the need for an alternative pest control strategy that is void of environmental damage has been increasing in recent time, primarily due to their long term viability (Borriss, 2015). In characterizing plants associated bacterial; biocontrol bacterial agents usually takes preeminent owing to their ability to suppress phytopathogens for enhanced plant health and reduce harvest loss. Production of antimicrobial secondary metabolites and siderophores and Stimulation of induced systemic resistance (a multifactorial process) is dependent on several compounds produced by the rhizobacteria e.g., c-LP surfactin and volatiles (Raaijmakers et al., 2010). However, a combine effects of these strategies could be necessary for improved crop yield through sound bioformulation of a number of viable microbial living spores (PGPR) and concentrated culture supernatants with antimicrobial metabolites (Borriss, 2015).

\section{Production of Antibiotics}

Antibiotics production is one of the most studied biocontrol strategies display by PGPR. Some good examples include amphisin, 2, 4-diacetylphloroglucinol (DAPG), oomycin-A, phenazine, pyoluteorin, pyrrolnitrin, tensin, tropolone and the cyclic lipopeptides synthesis (Loper and Gross, 2007). Basically, these biochemicals are produced by Pseudomonas strains, Bacillus, Streptomyces and Stenotrophomonas sp. As an active chemical agent, they are influenced by biotic and abiotic factors. Antibiotics are low weight molecular compound that suppress the development of plants pathogenic microorganisms. Phloroglucinols (Phl), Dgluconic acid and 2-hydroxymethyl-chroman-4-one have successfully been utilized as biocontrol agent (Kaur et al., 2006; Cazorla et al., 2006; Perneel et al., 2008). Phloroglucinol is a benzenetriol, primarily used in pharmaceutical production of Flopropione (Singh et al., 2010). Phloroglucinols are naturally found in certain plant species and are also produced by soil microorganisms. The 2,4-diacetylphloroglucinol (DAPG) is the widely studied phloroglucinol produced by Pseduomonads. Its causes membrane and zoospore damage in Pythium sp. These antibiotics acts as an inhibitor to aldose reductase, an enzyme involved in metabolism of glucose to fructose (Odoh et al., 2017). Phenazine also enhances the survival of bacteria in anaerobic conditions using endogenous phenazines, as withnessed in the survival of $P$. aeruginosa facilitated by extracellular electron transfer (Wang et al., 2010).

Elsewhere, increase productivity as a result of biocontrol inoculants was reported in $S$. rochei inhibition of pepper root rot caused by phytopthora (Ezziyyani et al., 2007); S. platensis against R. solani leaf blight/seedling blight of rice (Wan et al., 2008); Tomato wilt and fusarium root rot caused by $S$. griseoviridis (Minuto et al., 2006); S. hygroscopicus infection caused by Colletotrichum gloeosprioides anthacnose and in wide range of crops (Prapagdee et al., 2008).

\section{Competition for Nutrient and Space}

For rhizospheric bacteria to claim dormant over the rest of soil microorganisms, it must be able to compete favourably for the available nutrient and space. This is 
required to limit the incidence and severity of plant disease (Kamilova et al., 2005). Consequently, such adaptation makes the root unfit to host pathogens as a result of PGPR fast colonization. As a negative form of association, the most competent group of microorganisms takes charge and controls the whole metabolic activities. Aside the inherent growth which PGPR acquires via competition as a result of sufficient nutrient availability, other properties such as presence of flagellium, lipopolysaccharide, chemotaxis and the usage of secreted root exudates enhances their survival (Lugtenberg and Kamilova, 2009). A good illustration can be seen in unavailability of iron to phytopathogenic fungi when chelated by siderophores synthesized by PGPR. Conversely, iron is one of the essential nutrients required by all microorganisms for synthesis of ATP, formation of heme, reduction of ribotide precursors of DNA and a number of functions (Saraf et al., 2011). In niche competition, a physical occupation of site by PGPR is enhanced through delay tactics by preventing the colonization of pathogens until the available substrate is exhausted (Heydari and Pessarakli, 2010). This feature has been an age long adaptive property exerted by beneficial soil microorganisms to occupy the root rhizosphere and make available the scarce nutrient for their upkeep (Lugtenberg et al., 2001).

\section{Induced Systemic Resistance (ISR)}

PGPR triggers inducement of some kind of defense system known as Induced Systemic Resistance (ISR) that is capable of fighting some pathogenic bacteria, fungi and viruses. This potentially position the plant as strong and highly adapted specie (Van Loon, 2007). The gene and gene product involved in this form of biological control has been poorly documented. Unlike the systemic acquired resistance (SAR) (Handelsman and Stabb 1996), which is a state of defense that is activated all through the plant following primary infection by pathogens (Ryals et al., 1996). Induce Systemic Resistance (ISR) utilizes organic acid and plant hormones (salicylic acid, jasmonic acid and ethylene) in signaling and stimulation of the host plant defense response against variety of phytopathogens (Niranjan et al., 2005; Beneduzi et al., 2012; Pieterse et al., 2014). PGPR response to ISR is usually felt by increased physical and mechanical strength of the cell wall as well as adjustment of biochemical and physical reaction to environmental pressure (Labuschagne et al., 2010). ISR in PGPR can be in the form of salicylic acid, siderophores production, lipopolysaccharide, flagella, N-acyl homoserine lactone (AHL) molecules (Van Loon 2007; Shuhegger et al., 2006) and antibiotics. The participating organisms in this form of biocontrol include B. pumilus, Pseudomonas sp and enterobacteria (Jourdan et al., 2009). In a wider scale, application of PGPR strain as seed coat have improved tremendously the ISR against
Colletotrichum lagenarium which causes anthracnose in cucumber, Pseudomonas syringae causing angular leaf spot and bacterial wilt by Erwinia tracheiphila (Zehnder et al., 2001).

\section{Signal Interference}

For an organism (beneficial or pathogenic) to exert it effects, a particular quorum is required. This requirement especially in gram negative organisms is communicated via a small diffusible signaling molecule called N-Acyl Homoserine Lactone (AHL). This signal interference regulatory agent allows the cells to sense the population of their kind and to express certain character. The development of essential physiological characters such as production of pathogenicity/virulence factors, swarming, swimming, twitching motilities, and rhizosphere colonization can also be credited to cell signaling (Gray and Garey, 2001; Miller and Bassler 2001). The discovery of enzyme capable of degrading AHL is considered to be a fight in the right direction against phytopathogens quorum-sensing system, as $B$. thuringiensis has shown to efficiently decrease the incidence and development of potato soft rot caused by Erwinia carotovora using signal interference strategies (Dong et al., 2004).

\section{Production of Lytic Enzymes}

Also, synthesis of extracellular enzymes such as chitinases, B-1-3 glucanases, lipases, cellulases and proteases by rhizobacteria has been suggested to be a vital form of biocontrol (Markowich and Kononova 2003). They are hydrolytic enzymes that degrade wide range of compound usually of plant origin. They are also efficient in the lysing of fungal cell wall (Mabood et al., 2014). Palumbo et al. (2005) has suggested the significant of beta-1, 3-glucanase on the biocontrol activities of Lysobacter enzymogenes strain C3 against Bipolaris leaf spot caused by Phytium sp. As multifunctional organic protein, these enzymes form protection from desiccation and against abiotic and climatic factors (Qurashi and Sabri, 2012). Lytic enzyme can be used in the control of blight in pepper by Phytophthora capsici (Jung et al., 2005), Fusarium infection (Hariprasad et al., 2011) and sugar beet by Pythium ultimum (Dunne et al., 1997). Chaiharn et al. (2008) illustrated the antagonistic potential of PGPR through the production of chitinase, $\beta 1,3$ glucanase, proteolytic enzymes and cellulase at low concentration, even as Pseudomonas sp has proven to be a good candidate (Cattelan et al., 1999). Mycoparasitic and Trichoderma species has also been implicated in their antagonistic biocontrol activities against Rosellinia necatrix and other plant pathogens using chitinases (Hoopen and Krauss 2006; Harman et al., 2004). 


\section{Hydrogen Cyanide (HCN)}

Production of hydrogen cyanide (cyanogenesis) is predominantly associated to pseudomonas sp. Quantitatively, this can be detected using the techniques described by Lorck (1948). HCN, a volatile biocontrol agent has been well studied. Its cyanide ion inhibits metalloenzymes, principally in copper containing cytochrome c oxidases (Blumer and Haas, 2000). Cyanide produced by Pseudomonas strains has successfully been used to curb canker of tomato (Lanteigne et al., 2012). As a secondary metabolite produced by gram negative bacteria, it is formed from glycine and catalyzed by HCN synthase (Castric, 1994). P. fuorescens strain CHA0 (Voisard et al., 1989) was used to control tobacco black root rot caused by Thielaviopsis basicola (Laville et al., 1998). However, because of the aggressive colonizing strength of Pseudomonas fluorescens, it has effectively been used in the control of soil-born plant pathogens (Lugtenberg et al., 2001). There are indications that a good number of rhizobacteria has cyanogenic property when provided with glycine in their growth culture.

\section{Production of Siderophore}

Iron is a vital element needed by all forms of life. It is one of the most abundant mineral deposits on earth. The unavailability of biological forms of iron for plant utilization creates perplexing circumstances for their growth. Siderophore which means iron carrier or iron chelating is an important strategy developed to increase iron $\left(\mathrm{Fe}^{3+}\right)$ bioavailability as a unique constituent of cytochrome, enzymes co-factor and heme or non-heme proteins. Siderophores are low molecular weight biomolecules produced by microorganisms and has strong affinity with $\mathrm{Fe}^{3+}$ ions (Sureshbabu et al., 2016). When $\mathrm{Fe}$ is limited, microbial iron chelating agents (siderophores) scavenge and provide plants with $\mathrm{Fe}$ from the mineral phase through the formation of soluble $\mathrm{Fe}^{3+}$ complexes. Containment of soil borne phytopathogens by siderophore producing Pseudomonas has been reported (Buysens et al., 1996). Related studies has shown that siderophore production occurs in both gram positive and gram negative organisms with specific example of Bacillus, Rhodococcus, Enterobacter and Pseudomonas genera (Tian et al., 2009). Consequently, this property is also exhibited by some plant especially grasses (phyto-siderophores) (Van der Helm and Winkelmann, 1994), as they form constituent in fertilizer formulation, regulate iron intake capacity in plants and facilitate growth (Miller and Malouin, 1994).

One of the major challenges limiting efficient production of siderophore is environmental factors. These include $\mathrm{pH}$, soil iron level, their forms, presence of other trace elements, inadequate supply of carbon, nitrogen and phosphorus (Duffy and Défago, 1999).
However, siderophore mediated growth promoting activity of PGPR is associated with the suppression of root pathogens by competitive exclusion. Thus, preventing harmful microorganisms access to environmental iron by extracellular iron complex formation (Podile and Kishore, 2006; Ahemad and Khan, 2011; Saharan and Nehra, 2011). Also, works have shown that PGPR synthesis of siderophore improve not only the growth performance and adaptability in stress condition, but also enhance their ability to absorb both radioactive iron and rhizospheric metals iron even at low concentration (Robin et al., 2008; Dimkpa et al., 2009). Apart from creating favourable competitive room for bacteria against some pathogenic microorganisms by removing iron from the environment (Persello-Cartieaux et al. 2003), chelated iron has also proven to possess one of the weakest bond with fungi (Loper and Henkels, 1999). This condition seems possible considering the fact that many bacterial siderophores differ in their abilities to sequester iron leading to it biological and/or adaptive deprivation of the scarce commodity (iron). Iron chelating has also been linked with potential of promoting bacterial auxin synthesis by reducing the detrimental effects of heavy metals through chelation mechanism (Dimkpa et al., 2008).

\section{Biofertilization}

This is the application of microbial inoculants on seeds, plant surfaces, or soil to colonize root rhizosphere. This condition enhances growth through the supply and availability of primary nutrients to the plant. Mahdi et al. (2010) defined biofertilization as cultures of bacteria, fungi and algae either alone or in combination, packed in a carrier material. Bhardwaj et al. (2014; Arora et al., 2012) where of the view that biofertilization play a vital role in atmospheric nitrogen fixation, mineralization of organic compounds and phytohormones synthesis. It is an essential components of organic agriculture and vital in maintaining long-term soil fertility and sustainability through the production of safe and healthy food. With current campaign to halt the over dependent on chemically synthesized fertilizers, focus has been on harnessing the potential microorganisms for improved agrobiology (Afzal and Asghari, 2008; Bhardwaj et al., 2014). Inversely, the use of chemical base fertilizer to enhance soil fertility and crop yield has often negatively impinged on the complexity of both biotic and abiotic matter turnover (Perrott et al., 1992; Steinshamn et al., 2004). This is due to leaching and run-off of nutrients especially Phosphorus $(\mathrm{P})$ and Nitrogen $(\mathrm{N})$ resulting to poor soil quality (Tilman, 1998; Gyaneshwar et al., 2002). Chatzipavlidis et al. (2013) opined that for an efficient formation and utilization of biofertilizer, there must be proper preparation/formulation of the inoculants, selection of adequate carrier and designing 
of correct delivering system. However to achieve this, a scientific base research must be done to optimize this technology for commercial application, thereby increasing productivity through low cost and supporting economic viability for both small and marginal farmers (Boraste et al., 2009).

\section{Biofertilization Mode of Actions}

Here, a direct mechanism which enhance plants growth through nitrogen fixation and nutrient solubilization has been identified (Sandy and Butler, 2009; Bhattacharyya and Jha, 2012). Biofertilizers are the preparations containing cells of microorganisms which may be $\mathrm{N}$ fixers, $\mathrm{P}$ solubilizers, S- oxidisers or organic matter decomposers. They are called bioinoculants, which on supply to plants improve their growth and yield. As a bio healthy inoculants containing living cells of different types of microorganisms, they have the ability to mobilize nutritionally important elements from non-usable form through biological stress (Khan and Naeem, 2011; Mazid et al., 2012). During mycorrhiza colonization, bioactive ligands called Myc factors and Nod factors are secreted by mycorrhiza and rhizobium. The phenomenon is usually facilitated through a communication signal using a transduction pathway (Roberts et al., 2013), thus triggering further transduction pathway signal through some chemical receptors for the release of $\mathrm{Ca}^{2+}$ in the cytosol (Sieberer et al., 2009).

\section{Fixation of Nitrogen}

Nitrogen $(\mathrm{N})$ is a vital element for all forms of life. It is the most important nutrient for plant growth and also an essential constituent of nucleotides, membrane lipids and amino acids (Marschner, 1995). It constitutes the fourth most important plants dry mass. The biological fixation of atmospheric nitrogen is an important microbial activity for the maintenance of life on earth. This process occur when atmospheric nitrogen is converted to ammonia by an enzyme called nitrogenase; a highly complex oxygen labile enzyme conserved in free-living symbiotic diazotrophs (Franche et al., 2009). The process coupled with the hydrolysis of 16 equivalents of Adenosine Triphosphate (ATP) is accompanied by the co-formation of one molecule of $\mathrm{H}_{2}$. Considering the two types of nitrogen fixation (symbiotic and non-symbiotic) base on the plant involved and the associated group of organisms, it is agreed that non-symbiotic bacteria fix lesser amount of nitrogen than the root nodule bacteria (rhizobia) (James et al., 1997). In spite of their low fixing capacity, some PGPR have shown to be very effective in augmenting this process by making the scarce nutrient (nitrogen) available to plants.
In the event of non-symbiotic nitrogen fixing activities, free living diazotrophs stimulate the growth of non- leguminous plants. The genera identified in this group include Azoarcus, Azotobacter, Acetobacter, Azospirillum, Burkholderia, Diazotrophicus, Enterobacter, cyanobacteria, Pseudomonas and Gluconacetobacter (Anabaena, Nostoc) (Vessey, 2003; Bhattacharyya and Jha, 2012). While in symbiotic form, bacteria such as Rhizobium, Bradyrhizobium, Mesorhizobium, Sinorhizobium and Frankia (a nitrogen fixing Actinomycete), trees and shrubs (Zahran, 2001) exerts their functions. Application of cultures with diazotroph PGPR (non-symbiotic nitrogen fixing organisms) especially Azotobacter and Azospirillum has improved the yield of annual and perennial grasses (Tilak et al., 2005), just as cyanobacteria nitrogen fixation is essential in the cultivation of rice. Azotobacter also encourage high yield of wheat by over $30 \%$ (Gholami et al., 2009). The initiation of molecular dialogue between host plants and soil bacterial occurs through the release of signal in the form of communication chemicals such as flavonoid (Fig. 1) (Perret et al., 2000; Spaink, 2000). This molecule enhances plants-microbe relationship. Barriuso et al. (2008) observed that this chemical aid in the selection of most compactable partners for their growth and subsequent elimination of suspected harmful once. The communication signal is perceived by a bacteria receptor (NodD) and acts as a transcriptional activator of other nodulation genes $(\operatorname{nodA}, \operatorname{nodB}, \operatorname{nodC}$ and nodFE) (Franche et al., 2009). The Nod factors activate agent of root nodules residence in the rhizobia (Long, 2001).

\section{Solubilization of Phosphate}

Phosphate is next to nitrogen in the list of essential minerals mostly required by plants. However, their deficiency in soil limits crop growth (Nisha et al., 2014). It's an insoluble inorganic element which increases the economic viability of any agricultural product when solubilized. The organic forms are found mostly in humus and decayed organic materials. Phosphate represent about $0.2 \%$ of plants dry weight as it is essential constituent of nucleic acid, phytin and phospholipid. Moreover, its plays a key role in photosynthesis, respiration, storage and transfer of energy during cell division and elongation (Sagervanshi et al., 2012). A large portion of soluble inorganic phosphate is applied to the soil as fertilizer. Due to its rapid rate of fixation and complex formation with other soil elements, it is speedily immobilized and become unavailable to plants (Chatzipavlidis et al., 2013; Vikram and Hamzehzarghani, 2008). Organic materials constitute an important reservoir of immobilized phosphate, accounting for about $20-80 \%$ of total soil phosphorus. 


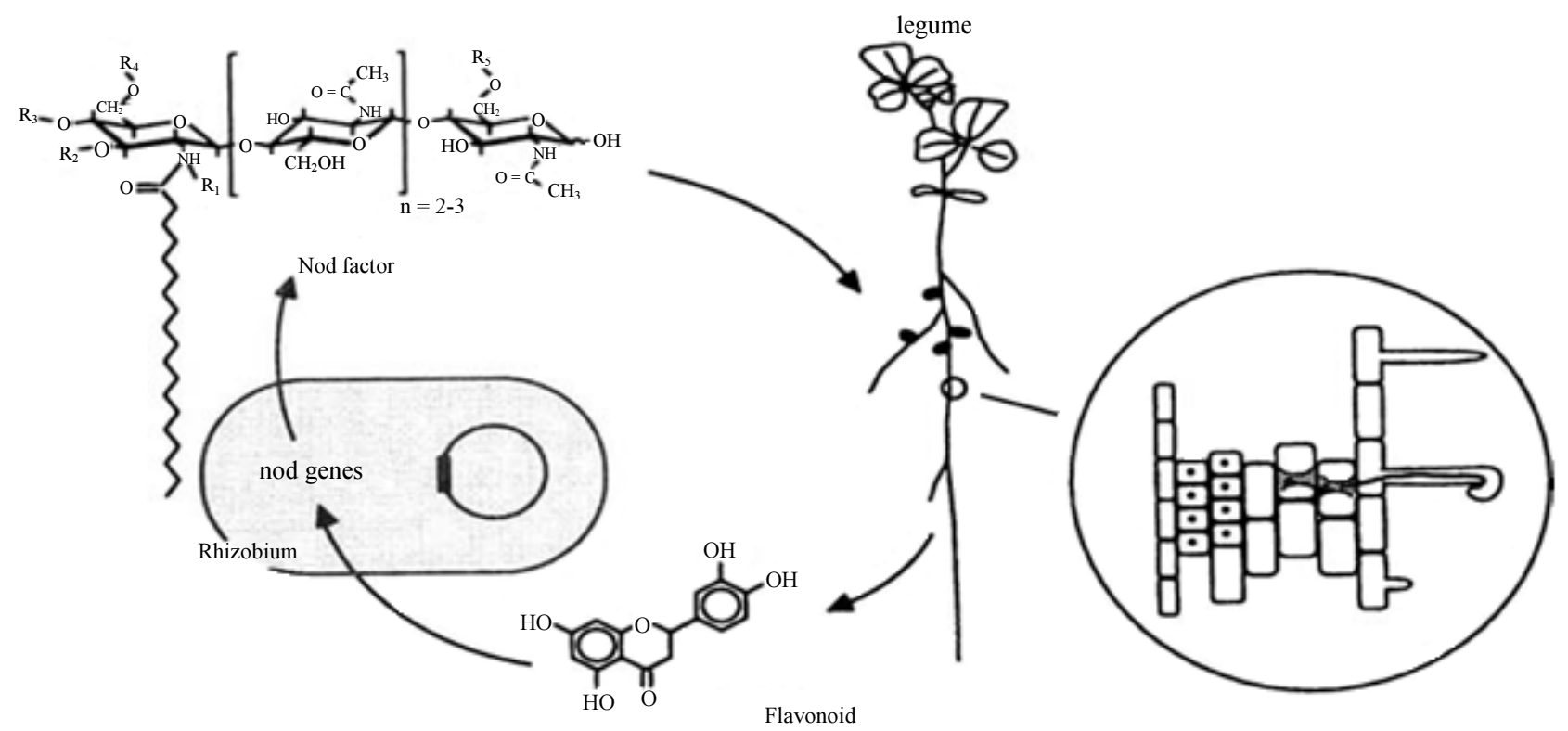

Fig. 1: Signal exchange in Rhizobium-plant symbiosis (Schultze and Kondorosi, 1998)

A greater proportion of insoluble inorganic phosphate (apatite) or insoluble organic phosphates (inositol phosphate, phosphomonesters and phosphotriesters) are inaccessible by plant (Khan et al., 2007; Chatzipavlidis et al., 2013; Pérez-Montano et al., 2014).

Microorganisms have been identified to play an important role in availing phosphorus to plants through their participation in soil phosphorus cycle. These organisms (PGPRs) directly solubilize and mineralize inorganic phosphorus and facilitate the mobility of the organic forms through biogeochemical cycle (Richardson and Simpson, 2011). Specifically, Phosphate Solubilizing Bacteria (PSB) such as Arthrobacter, Pseudomonas, Alcaligenes, Bacillus, Burkholderia, Serratia, Enterobacter, Acinetobacter, Azospirillum, Azotobacter, Flavobacterium, Rhizobium and Erwinia (Zaidi et al., 2009) have been implicated. Explicitly, each genus act independently to facilitate the dissolution and uptake of phosphate via In vitro condition (Ramachandran et al., 2007). The PSBs secrete organic acids e.g., carboxylic acid, formic acid, propionic acid, lactic acid, glycolytic acid, succinic and fumaric acid (Vazquez et al., 2000). Kaur et al. (2016) in their discovery established that these organic acids lowers the $\mathrm{pH}$ in the rhizosphere, thus causing release of the bound forms of phosphate like $\mathrm{Ca}_{3}(\mathrm{PO} 4)_{2}$ in the calcareous soils. Apart from creating the availability of accumulated phosphate, phosphorus biofertilization also help in increasing the efficiency of biological nitrogen fixation and the availability of $\mathrm{Fe}, \mathrm{Zn}$, etc., through production of plant growth promoting substances. PSB are also able to mineralize the insoluble organic phosphate through the excretion of extracellular enzymes such as phytases and C-P lyases phosphatases
(Weyens et al., 2010). Authors have reported increase yield of maize (Zea maize) (Yazdani et al., 2009), alfalfa (Medicago sativa L.) (Rodriguez and Fraga, 1999) and soybean (Glyxin max) (Abd-Alla, 2001), through PSB inoculation when applied singly or in combination of other rhizobacteria (Mahdi et al., 2010; Ahemad and Khan, 2011).

\section{Biostimulation}

These are organic chemical compounds that influence plant growth. They are also known as plant growth regulator or phytostimulant e.g.; Auxin (indole-3-acetic acid (IAA)), Gibberellic acid (GA), cytokinins and ethylene. These chemical molecules are recognized over the years as four major plant hormones needed for biochemical and physiological development. PGPR species belonging to the genera Bradyrhizobium, Acetobacter, Azospirillum, Xanthomonas, Alcaligenes, Azospirillum, Enterobacter, Pseudomonas and Klebsiella and also the species of Bacillus pumilus, $B$. licheniformis, Paenibacillus polymyxa, Phosphobacteria sp, Glucanoacetobacter sp, Aspergillus sp and Penicillium niger has the ability of producing phytohormones (Shobha and Kumudini, 2012; Chatzipavlidis et al., 2013).

\section{Biostimulation Mode of Actions}

These are PGPR phytostimulators also called plant growth regulator. They are plants exogenously synthesized hormones that regulate plants growth and developments. Its chemical structure is similar to that of natural plant hormones. The mechanism that is being projected is the production of phytohormones (plant 
hormones) such as auxins, cytokinins and GA (Somers et al., 2004). As an organic substance found in extremely low amounts that exert influence on the biochemical, physiological and morphological processes in plants; their production is efficiently regulated. IAA enhances plant nutrition and development, extensive differentiation and increasing rate of xylene and root development (Glick, 2012). Essentially, ethylenes are metabolite for normal growth and development, while cytokinin exercises its strength in plant root and shoots cell division (cytokinesis) (Khalid et al., 2006)

\section{Indole-3-Acetic Acid (Auxin)}

Auxin is an essential molecule that regulates directly or indirectly most plants processes. Being the first phytohormone discovered by Darwin (1880) using Phalaris canariensis seeds, it has since paved way for more discovery leading to identification of Indole-3Acetic Acid (IAA) as the most active and famous plant hormones of auxin group. Irrespective of plants being able to synthesize this chemical molecule (endogenously), they still depend largely on external supply (exogenous) for their optimum performance. This exterior demand is predominantly run by PGPR and associate soil bacterial (Patten and Glick, 2002; Khalid et al., 2006). Auxin function promptly through the formation of a number of cellular functions e.g., delineation of vascular tissues, initiation of lateral and adventitious roots, stimulation of cell division, elongation of stems and roots and orientation of root and shoot growth in response to light and gravity (Glick, 1995). For PGPR to produce IAA efficiently, the type of specie and strain, its culture condition, developmental stage and availability of nutrient in the rhizosphere are of important (Ashrafuzzaman et al., 2009). Although other auxins, such as indole-3-butyric acid (IBA) and phenyl acetic acid (PAA) have also been identified in plants (Normanly, 1997), their complexity and mode of actions are yet to be understood. Contrary, Bacteria IAA Producers (BIPs) are found to be most abundant in the soil/plant auxin pool and L-Tryptophan (L-TRP) as a precursor that aid increase and production of auxin. This was demonstrated in B. amyloliquefaciens FZB42 (Idris et al., 2007), Fluorescent Pseudomonas (Karnwal, 2009) and Azotobacter and Azospirillum strains in canola plant (Yasari and Patwardhan, 2007). Bartel (1997), proposed that rising level of LTryptophan increases the biochemical and metabolic activities of BIPs or Auxin Producing Bacterial (APBs), with a corresponding response in root length and modifications of root architecture. The four main metabolic pathways dependent of tryptophan are; tryptophol, ryptamine, indole-3-pyruvic acid and indole-3-acetamide pathway. Emerging evidence illustrate that organisms which produce low quantity of auxin as a result of absence of L-Tryptophan have the propensity of turning up high amount when augmented with L-tryptophan, especially in the presence of viable strain of Rhizobium (Zahir et al., 2010). It's interesting to note that even though the indigenous auxin (IAA) contribute to plant growth, its might still not be adequate for optimum growth performance. Hence, justifying the exogenous need of the chemical messenger (IAA produced by PGPR) to bring to the peak; plant growth, development and adaption to stressed environment.

\section{Gibberellic Acid Synthesis}

The exact mechanisms by which PGPR promote plants growth via the synthesis of gibberellic acid are not yet understood. It has been known that GA support the development of stem tissue, root elongation and lateral root extension (Yaxley et al., 2001). GA constitute a group of tetracyclic diterpenes that greatly influence the processes of seed germination, leaf expansion, stem elongation, fruit development, flower and trichome initiation (Yamaguchi, 2008). Because of their vital role in improving efficient photosynthetic processes in plants, gibberellins and its producing genera remains the primary target during environmental stress condition, making it an important plant growth bioregulator that can increase the stress tolerance of many crop plants. The improvement of plant growth by some rhizobacteria (PGPR) producing gibberellins was reported (Kang et al., 2009). The exogenous application of these growth hormones may be useful in amendment of polluted soil and improvement of crop performance (Iqbal et al., 2011). Application of GA has shown to increase considerably the grain yield in wheat (Iqbal et al., 2011), barley (Vettakkorumakankav et al., 1999) and tomato by decreasing stomatal resistance and improved water use efficiency (Maggio et al., 2010). Conclusively, gibberellin is involved in plant biochemical modification and stimulates the development of aerial part (Van Loon, 2007) as they remain an excellent alternative for inducing stress tolerant.

\section{Cytokinin Production}

Cytokinin play a significant role in cell division, vascular differentiation nutrient mobilization, chloroplast biogenesis, shoot differentiation, leaf senescence, apical dominance, anthocyanin production and photomorphogenic development (Davies, 2004). It participates also in vascular cambium sensitivity, proliferation of root hairs and contrarily in inhibition of lateral root formation and primary root elongation (Aloni et al., 2006). This molecule can be acquired endogenously and exogenously by either plant or PGPR respectively. Plants increase uptake of endogenous cytokinin via the promotion of biosynthesis (Pospíšilová, 2003b). Studies have shown that during plant growth, cytokinin perfectly regulates plant adaptation especially in salt polluted soil (Hadiarto and Tran, 2011). Biochemical studies have revealed that cytokinin serve as a major antagonist to 
Abscisic Acid (ABA), thus resulting in metabolic alteration of other phytohormones (Pospíšilová, 2003a). During water scarcity, plant cytokinin content reduces drastically with a resultant positive increase in ABA concentration. Assessing the production of plants hormones by different Streptomyces strains, in broth medium shows that all strains synthesized cytokinins and gibberellins (Mansour et al., 1994). Though this is vital for phyto development, its receptor gene in plants is often regulated by changes in osmotic conditions (Merchan et al., 2007).

\section{Ethylene}

Ethylene is a unique phytohormone with wide range of biological activities. The beneficial role of this biomolecule is best recorded at low concentration. Ethylene hinders some key developmental properties e.g., root elongation, induce defoliation and other cellular processes at high concentration resulting to reduced crop performance (Bhattacharyya and Jha, 2012). Pierik et al. (2006) was of the opinion that ethylene classification as a senescence hormone was due to its inhibitory role to plant growth. To overcome these alarming consequences, an enzyme 1Aminocyclopropane-1 Carboxylic acid (ACC) deaminase is needed. The role of this biocatalyst is to degrade the plant ACC which is the direct precursor of ethylene synthesis in plant to $\alpha$ - ketobutyrate and ammonium (Glick et al., 2007). The result of the degradation is the reduction of plant ethylene production through a range of mechanisms, while the PGPR producing ACC-deaminase regulates the ethylene level in plant and prevents the growth inhibition caused by high levels of ethylene (Noumavo et al., 2016). PGPR capable of inducing exogenous production of ethylene via degradation of the endogenous product using enzyme include Acinetobacter, Achromobacter, Agrobacterium, Alcaligenes, Azospirillum, Bacillus, Burkholderia, Enterobacter, Pseudomonas, Ralstonia, Serratia and Rhizobium. Works has shown that PGPR ACC deaminase activities were vital for Brassica napus growth (Dell'Amico et al., 2008). Pierik et al. (2006) suggested that at low concentration of ethylene mediated by PGPR, the plant yield, growth performance and germination properties of Arabidopsis thaliana get accelerated. However, this vaporous hormone regulate also root initiation, fruit ripening, seed germination, leaf abscission and wilting (Kaur et al., 2016).

\section{PGPR in Phytoremediation}

As soil constantly welcome large influx of waste materials, its overtime exert stern impact on the environment and human health. Most common of these pollutants are heavy metals ( $\mathrm{Hg}, \mathrm{Pb}, \mathrm{Cr}, \mathrm{Co}, \mathrm{Zn}, \mathrm{Ni}$ and $\mathrm{Cd}$ ). These metals have also been attributed to industrialization, urbanization and civilization (Odoh et al., 2017a). In agricultural practice, this form of pollution has been traced to human activities such as excessive fertilizer application, indiscriminate disposal of sewage and municipal waste and pesticides/insecticide usage. Though at immediate, these agro chemicals facilitate growth and productivity and subsequently leave records of metal residues that impair on plant growth and microbial metabolism at a long run. Because they are nonbiodegradable, their remediation process becomes extremely difficult, and can only be transform from one state to another. Soil rhizobacteria assisted phytoremediation has become an alternative of choice in detoxifying sites because it's cost effective, ecofriendly and aesthetic (Odoh et al., 2017b). Decontaminating these heavy metals polluted land occur through chelation, solubilization and mineralization using large consortium of soil microorganisms. These however aid their bioavailability/mobility and bioaccumulation during phytoremediation.

\section{Commercialization of PGPR and its Challenges in Africa}

Despite the knowledge gap of PGPR by agriculturists in the developing and less developed world, a good number of bacteria have long been used (Banerjee et al., 2006) for agro practices in advance countries and emerging economy (Table 2).

Although PGPR benefit is so enormous, its implementation is still at a developmental stage considering the increasing world population and demand for agricultural product. Effective and efficient utilization of this biotechnology for aggressive food production in the wake of rising food scarcity and humanitarian need is paramount. More In-situ research base approach should be carried out to ascertain the most suitable strain and appropriate biotic condition needed for growth, while paying good attention on the soil quality/property and season of their optimum performance.

There is need for government agencies in the tropics to enact policy and regulation regarding strain of organisms to be released into the environment (Glick, 2012) and also clarify their stake on genetically modified organisms as it will increase yield and turn-up in agrobiology.

More works need to be done in the tropics to commercialize agriculture i.e. (industrial agriculture) that has for decades been left in the hands of peasant farmers who are ill equipped with modern obtainable practice.

With the dwindling economy as a result of fall in oil price that has affected most mono-economy nation such as Nigeria. Agriculture still remain a lifelong viable revenue for the government, as more research need to be done to ascertain PGPRs strain-crop specificity and indebt soil analysis while considering African climatic condition. 


\begin{tabular}{|c|c|c|c|c|}
\hline Countries & Manufacturer & Product & Organisms & Crop \\
\hline Australia & $\begin{array}{l}\text { Mapleton AgriBiotec } \\
\text { pty Ltd }\end{array}$ & Twin N $®$ & $\begin{array}{l}\text { Azoarcus indigen NAB } 04 \\
\text { Azospirillum brasilense NAB } 317 \\
\text { Azorhizobium caulinoden NAB } 38\end{array}$ & $\begin{array}{l}\text { Sugar cane, Vegetables, } \\
\text { Cereals, Rape, Sugar beet }\end{array}$ \\
\hline Brazil & Embrafos Ltda & Bioativo ${ }^{\circledR}$ & PGPR consortia, organic matters & $\begin{array}{l}\text { Bean, maize, sugarcane, } \\
\text { rice, carrot, cotton }\end{array}$ \\
\hline Canada & $\begin{array}{l}\text { Lallen and plant care } \\
\text { BASF Inc. }\end{array}$ & $\begin{array}{l}\text { Rhizocell }{ }^{\circledR} \mathrm{GC} \\
\text { Nodulator }{ }^{\circledR}\end{array}$ & $\begin{array}{l}\text { B. amyloliquefaciens IT } 45 \\
\text { Bradyrhizobium japonicum }\end{array}$ & $\begin{array}{l}\text { Cereals and horticultural } \\
\text { plants }\end{array}$ \\
\hline China & $\begin{array}{l}\text { China Bio-Fertilizer } \\
\text { AG }(\mathrm{CBF})\end{array}$ & & PGPR consortia & \\
\hline Cuba & Labiafam S.A & Nitrofix ${ }^{\circledR}$ & Azospirillum $\mathrm{sp}$ & $\begin{array}{l}\text { Wheat, barley, carrot, } \\
\text { maize, cabbage }\end{array}$ \\
\hline France & Biovitis & Ceres $₫$ & P. fluorescens & Horticultural crop \\
\hline Finland & Kemira Agro Oy, & Mycostop ${ }^{\circledR}$ & Streptomycine griseoviridis & $\begin{array}{l}\text { Ornamentals, Tree } \\
\text { seedlings }\end{array}$ \\
\hline Germany & AbiTEP GmbH & FZB 24 ® fl & B. amyloliquefaciens $\mathrm{sp}$, plantarium & Vegetables \\
\hline Hungary & Agro bio Hungary kft & BactofilA10® & $\begin{array}{l}\text { A. Brasilence, } A \text {. Vinelandi, } \\
\text { B. megaterium, P. fluorescens }\end{array}$ & Cereals \\
\hline India & Biomax & $\begin{array}{l}\text { Greenmax } \\
\text { AgroTech } \\
\text { Life } \AA \text {, Biomix }{ }^{\circledR}, \\
\text { Biozink }{ }^{\circledR}, \text { Biodine } \AA \\
\text { Gmax PGPR }\end{array}$ & $\begin{array}{l}\text { PGPR consortia } \\
\text { Azotobacter, } P \text {. fluorescens, } \\
\text { phosphobacteira }\end{array}$ & $\begin{array}{l}\text { wide range of plant } \\
\text { variety } \\
\text { Field crops }\end{array}$ \\
\hline Italy & CCS Aosta Srl & Micosat F® cereali & $\begin{array}{l}\text { B. subtillis BR62, Peanibacillum } \\
\text { durus } \text { PD74, Streptomyces sp ST60 }\end{array}$ & $\begin{array}{l}\text { Tomato, soybean, } \\
\text { cereals, beet, sunflower }\end{array}$ \\
\hline Japan & $\begin{array}{l}\text { Tokachi Federation } \\
\text { of Agricultural } \\
\text { Cooperatives (TFAC) }\end{array}$ & 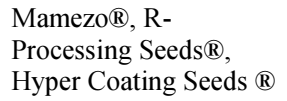 & $\begin{array}{l}\text { Rhizobium based formulation in } \\
\text { peat, legume seeds and grass } \\
\text { legume seed. }\end{array}$ & Legumes \\
\hline $\begin{array}{l}\text { New } \\
\text { Zealand }\end{array}$ & Borty-Zen 2010 Ltd & Armour-Zen $®$ & $\begin{array}{l}\text { Chitosan. An elicitor against } \\
\text { Botrytis cinerea (grey mould), } \\
\text { Sclerotinia scherofiorum (white rot) }\end{array}$ & Grapevine, ornamentals \\
\hline Spain & LAB (Labiotech) & Inomix ${ }^{\circledR}$ biostimulant & $\begin{array}{l}\text { B. polymyxa }(\mathrm{LAB} / \mathrm{BP} / 01) \\
B \text { sutilis }(\mathrm{LAB} / \mathrm{BS} / \mathrm{F} 1)\end{array}$ & Cereals \\
\hline $\begin{array}{l}\text { United } \\
\text { Kingdom (UK) }\end{array}$ & Cleveland biotech & Amnite A $100 ®$ & $\begin{array}{l}\text { Azetobacter, Bacillus, Rhizobium, } \\
\text { Cheatonium, Pseudomonas }\end{array}$ & $\begin{array}{l}\text { Cocumber, lettuce, } \\
\text { tomato, peper }\end{array}$ \\
\hline United & AgBioChem & Galtrol $®$ & Ageobacterium radiobacter strain 84 & Ornamentals, Fruits, Nuts \\
\hline $\begin{array}{l}\text { States of } \\
\text { America } \\
\text { (USA) }\end{array}$ & $\begin{array}{l}\text { Plant Health Care } \\
\text { Bio works }\end{array}$ & $\begin{array}{l}\text { Complete } \AA \text { plus } \\
\text { Trichodex }{ }^{\circledR}\end{array}$ & $\begin{array}{l}\text { B. pumilus, B subtilis, B. licheniformis, } \\
\text { B. polymyxa, B. azotofixan, B. megaterium } \\
\text { Trichoderma harzianum T-39 }\end{array}$ & $\begin{array}{l}\text { Nursery trees and field crop } \\
\text { Food crops }\end{array}$ \\
\hline
\end{tabular}

There is need for proper campaign and education of local populace on the important of genetically modified organisms and microbial inoculants in agro base practice, so as to explore the full potential of her rich fertile land for sustainable food production.

\section{Conclusion}

Decades ago, for an agricultural practice to be successful one must not neglect the use of chemical fertilizer, herbicides and pesticides. At an initial point, these chemicals aid plant growth and later exert their negative effects. This norm has not only affected the soil and its inhabitant but also renders threat to human life through the food chain. With rise in soil pollution, change in climatic condition, soil-born pathogen and extensive land overuse, the soil has become grossly infertile and unproductive; this is evident in the low agricultural output, food insecurity amidst the rising human population. To achieve self-sufficiency, effort must be made especially in the tropics to key into scientific knowledge through broad understanding of soil-plant-microbial interaction and their mechanism of action; this will not only lead to bumper harvest but keep the soil safe and healthy. As campaign for the use of PGPR gets heightened, attention should be focused on substituting agrochemicals with bioproduct formulated with consortium of beneficial PGPR. Highlighted advantages of these products in terms of; increased plant nutrient and biocontrol through induction of systemic resistance and nutrients and/or space competition must be carefully stated and comprehended by farmers for enhanced crop yield. Concussively, genetic engineering of PGPR as an integral constituent in modern food production will mitigate soil pollution, ecosystem alteration and destruction of soil flora and fauna when properly harnessed especially in developing economy.

\section{Acknowledgement}

The authors present a special thanks to Chief $\mathrm{Mr}$ and Mrs Sebastian Odoh for their encouragement, insight and motivation while preparing the manuscript. 


\section{Author's Contributions}

Odoh Chuks Kenneth: He is the lead author and responsible for the drafting of the manuscript, defining concepts and reviewed literatures.

Eze Chibuzor Nwadibe: Supervised and approved the final manuscript.

Akpi Uchenna Kalu: Helped in coordination and editing of the manuscript.

Unah Victor Unah: Controlling abstract as well as in adjusting the paper template.

\section{Ethics}

The article is original and the authors have declared no conflict of interest.

\section{References}

Abd-Alla, M.H, 2001. Regulation of nodule formation in soybean-Bradyrhizobium symbiosis is controlled by shoot or/and root signals. J. Plant Grow. Regul., 34: 241-250.

Adesemoye, A.O., H.A. Torbert and J.W. Kloepper, 2008. Enhanced plant nutrient use efficiency with PGPR and $\mathrm{AMF}$ in an integrated nutrient management system. Can. J. Microbiol., 54: 876-886. DOI:10.1139/W08-081

Afzal, A. and B. Asghari, 2008. Rhizobium and phosphate solubilizing bacteria improve the yield and phosphorus uptake in wheat. Int. J. Agric. Biol., 10: 85-88. DOI: 07-092/MFA/2008/10-1-85-88

Ahemad, M. and M.S. Khan, 2011. Functional aspects of plant growth promoting rhizobacteria: Recent advancements. Microbiol. Insights, 1: 39-54. DOI: 10.5567/IMICRO-IK.2011.39.54

Ahmad, F., I. Ahmad and M.S. Khan, 2008. Screening of free-living rhizospheric bacteria for their multiple plant growth promoting activities. Microbiol. Res., 163: 173-181. DOI: 10.1016/j.micres.2006.04.001

Ahmad, M., Z.A. Zahir, M. Khalid, F. Nazli and M. Arshad, 2013. Efficacy of rhizobium and pseudomonas strains to improvephysiology, ionic balance and quality of mung bean under saltaffected conditions on farmer's fields. Plant Physiol. Bioch., 63: 170-176.

DOI: $10.1016 /$ j.plaphy.2012.11.024

Alalaoui, A.C., 2007. Fertilisation minérale des cultures: Les éléments fertilisants majeurs (Azote, Potassium et Phosphore). Bull. Mens Inform. Liaison., 155: 1-4.

Aloni, R., E. Aloni, M. Langhans and C.I. Ullrich, 2006. Role of cytokinin and auxin in shaping root architecture: Regulating vascular differentiation, lateral root initiation, root apical dominance and root gravitropism. Ann. Bot., 97: 883-893.

DOI: $10.1093 / \mathrm{aob} / \mathrm{mcl} 027$ PMC2803412
Anjum, M.A., M.R. Sajjad, N. Akhtar, M.A. Qureshi and A. Iqbal et al., 2007. Response of cotton to Plant Growth Promoting Rhizobacteria (PGPR) inoculation under different levels of nitrogen. J. Agric. Res., 45: 135-143.

Antoun, H., C.J. Beauchamp, N. Goussard, R. Chabot and R. Llande, 2004. Potential of rhizobium and bradyrhizobioum species as plant growth promoting rhizobacteria on non-legumes: Effect on radishes. Plant Soil, 204: 57-67.

Arora, N.K., E. Khare, J.H. Oh, S.C. Kang and D.K. Maheshwari, 2008. Diverse mechanisms adopted by fluorescent Pseudomonas PGC2 during the inhibition of Rhizoctonia solani and phytopthora capsisi. World J. Microbiol. Biotech., 24: 581-585. DOI: $10.1007 / \mathrm{s} 11274-007-9505-5$

Arora, N.K., S. Tewari, S. Singh, N. Lal and D.K. Maheshwari, 2012. PGPR for Protection of Plant Health Under Saline Conditions. In: Bacteria in Agrobiology: Stress Management, Maheshwari, D.K., (Ed.) pp: 239-258.

Arshad, M. and W.T. Frankenberger, 1992. Soil Microbial Ecology. In: Microbial Production of Plant Growth Regulators, Metting, F.B. (Ed.), Marcel Dekker, Inc., New York.

Ashrafuzzaman, M., F.A. Hossen, M.R. Ismail, M.A. Hoque and Z.M. Islam et al., Meon, 2009. Efficiency of Plant Growth-Promoting Rhizobacteria (PGPR) for the enhancement of rice growth. Afr. J. Biotech., 8: 1247-1252.

Banerjee, M.R., L. Yesmin and J.K. Vessey, 2006. Plant Growth Promoting Rhizobacteria as Biofertilizers and Biopesticides. In: Handbook of Microbial Biofertilizers, Rai M.K. (Ed.), Haworth Press, Inc., New York.

Barriuso, J., B.R. Solano, R.G. Fray, M. Cámara and A. Hartmann et al., 2008. Transgenic tomato plants alter quorum sensing in plant growth-promoting rhizobacteria. Plant Biotech. J., 6: 442-452. DOI: $10.1111 /$ j.1467-7652.2008.00331.x

Bartel, B., 1997. Auxin biosynthesis. Ann. Rev. Plant Physiol. Plant Molecular Biol., 48: 51-66.

DOI: 10.1146/annurev.arplant.48.1.51

Belimov, A.A. and K.J. Dietz, 2000. Effect of associative bacteria on element composition of barley seedlings grown in solution culture at toxic cadmium concentrations. Microbiol. Res., 155: 113-121. PMID: 10950194

Beneduzi, A., A. Ambrosini and L.M.P. Passaglia, 2012. Plant Growth-Promoting Rhizobacteria (PGPR): their potential as antagonists and biocontrol agents. Genet. Mol. Biol., 35: 1044-1051. PMCID: PMC3571425

Bent, E., S. Tuzun, C.P. Chanway and S. Enebak, 2001. Alterations in plant growth and in root hormone levels of lodgepole pines inoculated with rhizobacteria. Can. J. Microbiol., 47: 793-800. PMID: 11683460 
Bhardwaj, D., M.W. Ansari, R.K. Sahoo and N. Tuteja, 2014. Biofertilizers function as key player in sustainable agriculture by improving soil fertility, plant tolerance and crop productivity. Microbial Cell Fact., 13: 1-10. DOI: 10.1186/1475-2859-13-66

Bhattacharyya, P. and D. Jha, 2012. Plant Growth Promoting Rhizobacteria (PGPR): Emergence in agriculture. World J Microbiol. Biotechnol., 28: 1327-1350. DOI: 10.1007/s11274-011-0979-9

Blumer, C. and D. Haas, 2000. Mechanisms, regulation and ecological role of bacterial cyanide byiosynthesis. Arch. Microbiol., 173: 170-177. PMID: 10763748

Boraste, A., K.K. Vamsi, A. Jhadav, Y. Khairnar and N. Gupta et al., 2009. Biofertilizers: A novel tool for agriculture. Int. J. Microbiol. Res., 1: 23-31.

Borriss, R., 2015. Towards a New Generation of Commercial Disease Control and Plant Growth Promotion Products. In: Principles of PlantMicrobe Interactions. Microbes $\mathrm{f}$ or Sustainabl e Agriculture, Lugtenberg, B. (Ed.), Springer, Berlin, pp: 329-337.

Bowen, G.D. and A.D. Rovira, 1999. The rhizosphere and its management to improve plant growth. Adv. Agron., 66: 1-102.

Broeckling, C.D., A.K. Broz, J. Bergelson, D.K. Manter and J.M. Vivanco, 2008. Root exudates regulate soil fungal community composition and diversity. Applied Environ. Microbiol., 74: 738-744. DOI: 10.1128/AEM.02188-07

Burd, G.I., D.G. Dixon and B.R. Glick, 2000. Plant growth promoting bacteria that decrease heavy metal toxicity in plants. Can. J. Microbiol., 46: 237-245. PMID: 10749537

Buysens, S., K. Heungens, J. Poppe and M. Hofte, 1996. Involvement of pyochelin and pyoverdin in suppression of Pythium-induced damping-off of tomato by Pseudomonas aeruginosa 7NSK2. Applied Environ. Microbiol., 62: 865-871. PMID: 16535275

Cakmakci, R., F. Donmez, A. Aydm and F. Sahin, 2006. Growth promotion of plants by plant growth promoting rhizobacteria under greenhouse and two different field soil conditions. Soil Biol. Biochem., 38: 1482-1487. DOI: 10.1016/j.soilbio.2005.09.019

Cakmakci, R., M. Erat, U. Erdogan and M.F. Donmez, 2007. The influence of plant-growth-promoting rhizobacteria on growth and enzyme activities in wheat and spinach plants. J. Plant Nutrit. Soil Sci., 170: 288-295.

Castric, P., 1994. Influence of oxygen on the Pseudomonas aeruginosa hydrogen cyanide synthase. Curr. Microbiol., 29: 19-21.

DOI: $10.1007 / \mathrm{BF} 01570186$
Cattelan, M.E., P.G. Hartel and J.J. Uhrmann, 1999. Screening of plant growth promoting rhizobacteria to promote early soybean growth. Soil Sci. Society Am. J., 63: 1670-1680.

Cazorla, F.M., S.B. Duckett, E.T. Bergstr€om, S. Noreen and R. Odijk et al., 2006. Biocontrol of avocado dematophora root rot by antagonistic Pseudomonas fluorescens PCL1606 correlates with the production of 2-hexyl 5-propyl resorcinol. Mol. Plant-Microbe Interact. J., 19: 418-428 DOI: 10.1094/MPMI-19-0418

Chaiharn, M., S. Chunhaleuchanon, A. Kozo and S. Lumyong, 2008. Screening of rhizobacteria for their plant growth promoting activities. KMITL Sci. Tech. J., 8: 18-23.

Chatzipavlidis, I., I. Kefalogianni, A. Venieraki and W. Holzapfel, 2013. Status and trends of the conservation and sustainable use of microorganisms in agroindustrial processes. Commission on Genetic Resources for Food and Agriculture, Background Study Paper No. 64.

Compant, S., C. Clément and A. Sessitsch, 2010. Plant growth promoting bacteria in the rhizo and endosphere of plants: Their role, colonization, mechanisms involved and prospects for utilization. Soil Biol. Biochem., 42: 669-678. DOI: $10.1016 /$ j.soilbio.2009.11.024

Darwin, F., 1880. Life and Letters of Charles Darwin. 1st Edn., pp: 506.

Dastager, S.G., C.K Deepa and A. Pandey, 2010. Potential plant growth promoting activity of Serratianematophila NII- 0.928 on black papper (Piper nigrum L.). World J. Microbiol. Biotech., 27: 259-265.

Davies, P.J., 2004. Plant hormones: Biosynthesis, Signal Transduction, Action. 3rd Edn., Kluwer Academic Publishers, Dordrecht.

Dell'Amico, E., L. Cavalca and V. Andreoni, 2008. Improvement of Brassica napus growth under cadmium stress by cadmium-resistant rhizobacteria. Soil Biol. Biochem., 40: 74-84.

Dimkpa, C.O., A. Svatos, P. Dabrowska, A. Schmidt and W. Boland et al., 2008. Involvement of siderophores in the reduction of metal-induced inhibition of auxin synthesis in Streptomyces sp. Chemosphere, 74: 19-25. DOI: 10.1016/j.chemosphere.2008.09.079

Dimkpa, C.O., D. Merten, A. Svatos, G. Büchel and E. Kothe, 2009. Siderophores mediate reduced and increased uptake of cadmium by Streptomyces tendae F4 and sunflower (Helianthus annuus), respectively. J. Appl. Microbiol., 107:1687-1696. DOI: $10.1111 / \mathrm{j} .1365-2672.2009 .04355 . \mathrm{x}$

Dong, Y.H., X.F. Zhang, J.L. Xu and L.H. Zhang, 2004. Insecticidal bacillus thuringiensis silences erwinia carotovora virulence by a new form of microbial antagonism, signal interference. Applied Environ. Microbiol., 70: 954-960.

DOI: 10.1128/AEM.70.2.954-960.2004 
Duffy, B.K. and G. Défago, 1999. Environmental factors modulating antibiotic and siderophore biosynthesis by Pseudomonas fluorescens biocontrol strains. Applied Environ. Microbiol., 65: 2429-2438. PMID: 10347023

Dunne, C., J.J. Crowley, Y. Moe“nne-Loccoz, D.N. Dowling and F.J. de Bruijn et al., 1997. Biological control of pythium ultimum by stenotrophomonas maltophilia W81 is mediated by an extracellular proteolytic activity. Microbiology, 143: 3921-3931.

Egamberdieva, D. and B. Lugtenberg, 2014. Use of Plant Growth-Promoting Rhizobacteria to Alleviate Salinity Stress in Plants. Use Microbes Alleviat. Soil Stresses, 1: 73-96.

Egamberdiyeva, D., 2007. The effect of plant growth promoting bacteria on growth and nutrient uptake of maize in two different soils. Applied Soil Ecol., 36: 184-189. DOI: 10.1016/j.apsoil.2007.02.005

El-Akhal, M.R., A. Rincon, T. Coba de la Peña, M.M. Lucas and N. El Mourabit et al., 2013. Effects of salt stress and rhizobial inoculation on growth and nitrogen fixation of three peanut cultivars. Plant Biol., 15: 415-421. DOI: $10.1111 / \mathrm{j} .1438-8677.2012 .00634 . \mathrm{x}$

Ezziyyani, M., M.E. Requena, C. Egea-Gilabert and M.E. Candela, 2007. Biological control of phytophthora root rots of pepper using trichoderma harzianum and streptomyces rochei in combination. Phytopathology, 155: 342-349. DOI: $10.1111 / \mathrm{j} .1439-0434.2007 .01237 . x$

Flores-Felix, J.D., E. Menendez, L.P. Rivera, M. Marcos-García and P. Martínez-Hidalgo et al., 2013. Use of Rhizobium leguminosarum as potential biofertilizer for Lactuca sativa and Daucus carota crops. J. Plant Nutri. Soil Sci., 176: 876-882. DOI: 10.1002/jpln.201300116

Flores-Felix, J.D., L.R. Silva and L.P. Rivera, 2015. Plants probiotics as a tool to produce highly functional fruits: The case of Phyllobacterium and vitamin $C$ in strawberries. PLoS ONE.

Foster, R.C., 1988. Microenvironments of soil organisms. Biol. Fertility Soils, 6: 189-203. DOI: $10.1007 /$ BF00260816

Franche, C., K. Lindstrom and C. Elmerich, 2009. Nitrogen-fixing bacteria associated with leguminous and non-leguminous plants. Plant Soil, 321: 35-59. DOI: $10.1007 /$ s 11 104-008-9833-8

Garcia-Fraile, P., L. Carro and M. Robledo, 2012. Rhizobium promotes non-legumes growth and quality in several production steps: Towards a biofertilization of edible raw vegetables healthy for humans. PLoS ONE

Gholami, A., S. Shahsavani and S. Nezarat, 2009. The effect of Plant Growth Promoting Rhizobacteria (PGPR) on germination, seedling growth and yield of maize. World Acad. Sci. Eng. Tech., 3: 1-14.
Glick, B.R., 2012. Plant growth-promoting bacteria: Mechanisms and applications. Scientifica, 2012: 1-15. DOI: 10.6064/2012/963401

Glick, B.R., 1995. The enhancement of plant growth by free-living bacteria. Can. J. Microbiol., 41: 109-117. DOI: $10.1139 / \mathrm{m} 95-015$

Glick, B.R., D.M. Penrose and J.P. Li, 1998. A model for the lowering of plant ethylene concentrations by plant growth-promoting bacteria. J. Theoretical Biol., 190: 63-68. DOI: 10.1006/jtbi.1997.0532

Glick, B.R., Z. Cheng, J. Czarny and J. Duan, 2007. Promotion of plant growth by ACC deaminaseproducing soil bacteria. Eur. J. Plant Pathol., 119: 329-339. DOI: $10.1007 / \mathrm{s} 10658-007-9162-4$

Gray, K.M. and J.R. Garey, 2001. The evolution of bacterial LuxI and LuxR quorum sensing regulators. Microbiology, 147: 2379-2387.

DOI: $10.1099 / 00221287-147-8-2379$

Gyaneshwar, P., G.N. Kumar, L.J. Parekh and P.S. Poole, 2002. Role of soil microorganisms in improving $\mathrm{P}$ nutrition of plants. Plant Soil, 245: 83-93. DOI: 10.1023/A:1020663916259

Hadiarto, T. and L.S. Tran, 2011. Progress studies of drought-responsive genes in rice. Plant Cell Rep., 30: 297-310. DOI: 10.1007/s00299-010-0956-z

Haghighi, B.J., O. Alizadeh and A.H. Firoozabadi, 2011. The role of Plant Growth Promoting Rhizobacteria (PGPR) in Sustainable Agriculture. Adv. Environ. Biol., 5: 3079-3083.

Handelsman, J and E.V. Stabb, 1996. Biocontrol of soilborne plant pathogens. Plant Cell, 8: 1855-1869. DOI: $10.1105 /$ tpc.8.10.1855

Hariprasad, P., S.T. Divakara and S.R. Niranjana, 2011. Isolation and characterization of chitinolytic rhi- zobacteria for the management of Fusarium wilt in tomato. Crop Prot., 30: 1606-1612. DOI: 10.1016/j.cropro.2011.02.03

Harman, G.E., C.R. Howel, A. Viterbo, I. Chet and M. Lorito, 2004. Trichoderma species-opportunistic, avirulent plant symbionts. Nat. Rev. Microbiol., 2: 43-56. DOI: $10.1038 /$ nrmicro797

Heydari, A. and M. Pessarakli, 2010. A review on biological control of fungal plant pathogens using microbial antagonists. J. Biol. Sci., 10 273-290. DOI: $10.3923 /$ jbs.2010.273.290

Hoopen, G.M. and U. Krauss, 2006. Biology and control of Rosellinia bunodes, Rosellinia necatrix and Rosellinia pepo: A review. Crop Prot., 25: 89-107.

Idris, S.E., D.J. Iqlesias, M. Talon and R. Borriss, 2007. Tryptophan-dependent production of Indole-3Acetic Acid (IAA) affects level of plant growth promotion by Bacillus amyloliquefaciens FZB42. Mol. Plant-Microbe Interact., 20: 619-626. DOI: 10.1094/MPMI-20-6-0619

Iqbal, N., R. Nazar, M.I.R. Khan, A. Masood and N.A. Khan, 2011. Role of gibberellins in regulation of source sink relations under optimal and limiting environmental conditions. Curr. Sci., 100: 998-1007. 
Jackson, T., 1992. Renewable energy; summary paper for renewable series. Energy Policy, 20: 861-883.

James, E.K., F.L. Olivares, J.L. Baldani and J. Döbereiner, 1997. Herbaspirillum, an endophytic diazotroph colonizing vascular tissue in leaves of Sorghum bicolor L. Moench. J. Exp. Bot., 48: 785-797. DOI: $10.1093 / \mathrm{jxb} / 48.3 .785$

Joo, G.J., Y.M. Kim, J.T. Kim, I.K. Rhee and J.H. Kim et al., 2005. Gibberellins-producing rhizobacteria increase endogenous gibberellins content and promote growth of red peppers. J. Microbiol., 43: 510-515. PMID: 16410767

Jourdan, E., G. Henry, F. Duby, J. Dommes and J.P. Barthelemy et al., 2009. Insights into the defenserelated events occurring in plant cells following perception of surfactin-type lipopeptide from Bacillus subtilis. Mol. Plant Microbol. Interact., 22: 456-468. DOI: 10.1094/MPMI-22-4-0456

Junaid, J.M., N.A. Dar, T.A. Bhat, A.H. Bhat and M.A. Bhat, 2013. Commercial biocontrol agents and their mechanism of action in the management of plant pathogens. Int. J. Mod. Plant Ani. Sci., 1: 39-57.

Jung, W.J., Y.L. Jin, K.Y. Kim, R.D. Park and T.H. Kim, 2005. Changes in pathogenesis-related proteins in pepper plants with regard to biological control of phytopthora blight with Paenibacillus illinoisensis. BioControl, 50: 165-178.

DOI: $10.1007 / \mathrm{s} 10526-004-0451-\mathrm{y}$

Kamilova, F., S. Validov, T. Azarova, I. Mulders and B. Lugtenberg, 2005. Enrichment for enhanced competitive plant root tip colonizers selects for a new class of biocontrol bacteria. Environ. Microbiol., 7: 1809-1817.

DOI: $10.1111 / \mathrm{j} .1462-2920.2005 .00889 . x$

Kang, S., G.J. Joo and M. Hamayun, 2009. Gibberellin production and phosphate solubilization by newly isolated strain of Acinetobactercalcoaceticus and its effect on plant growth. Biotech. Lett., 31: 277-281. DOI: $10.1007 /$ s10529-008-9867-2

Karnwal, A., 2009. Production of indole acetic acid by Fluorescent Pseudomonas in the presence of LTryptophan and Rice root exudates. J. Plant Pathol., 91: 61-63.

Kaur, H., J. Kaur and R. Gera, 2016. Plant growth promoting rhizobacteria: A boon to agriculture. Int. J. Cell Sci. Biotech., 5: 17-22.

Kaur, R., J. Macleod, W. Foley and M. Nayudu, 2006. Gluconic acid, an antifungal agent produced by Pseudomonas species in biological control of take all. Phytochemistry, 67: 595-604. DOI: $10.1016 /$ j.phytochem.2005.12.011

Khalid, A., M.J. Akhtar, M.H. Mahmood and M. Arshad, 2006. Effect of substrate-dependent microbial ethylene production on plant growth. Microbiology, 75: 231-236. DOI: 10.1134/S0026261706020196
Khan, A.L., M. Waqas and S.M. Kang, 2014a. Bacterial endophyte Sphingomonas sp. LK11 produces gibberellins and IAA and promotes tomato plant growth. J. Microbiol., 52: 689-695.

Khan, Z.R., C.A.O. Midega, J.O. Pittchar, A.W. Murage and M.A. Birkett et al., 2014b. Achieving food security for one million sub-Saharan African poor through push-pull innovation by 2020. Philosophical Trans. Royal Society B, 369: 1-11. DOI: $10.1098 /$ rstb.2012.0284

Khan, M.S., A. Zaidi and M. Aamil, 2002. Biocontrol of fungal pathogens by the use of plant growth promoting rhizobacteria and nitrogen fixing microorganisms. J. Indian Bot. Society, 81: 255-263.

Khan, M.S., A. Zaidi and P.A. Wani, 2007. Role of phosphate solubilizing microorganisms in sustainable agriculture- a review. Agron. Sustain. Dev., 27: 29-43. DOI: 10.1051/agro:2006011

Khan, T.A. and A. Naeem, 2011. An alternate high yielding inexpensive procedure for the purification of concanavalin A. Biol. Med., 3: 250-259.

Kloepper, J.W., J. Leong, M. Teintze and M.N. Schroth, 1980. Enhanced plant growth by siderophores produced by plant growthpromoting rhizobacteria. Nature, 286: 885-886. DOI: $10.1038 / 286885 \mathrm{a} 0$

Kumar, H., V.K. Bajpai and R.C. Dubey, 2010. Wilt disease management and enhancement of growth and yield of Cajanus cajan (L) var. Manak by bacterial combinations amended with chemical fertilizer. Crop Prot., 29: 591-598.

Labuschagne, N., T. Pretorius and A.H. Idris, 2010. Plant Growth Promoting Rhizobacteria as Biocontrol Agents Against Soil-Borne Plant Diseases. In: Plant Growth and Health Pro- Moting Bacteria, Microbiology Monographs, Maheshwari, D.K. (Ed.), SpringerVerlag Berlin Heldelberg, pp: 211-230.

Lanteigne, C., V.J. Gadkar, T. Wallon, A. Novinscak and M. Filion, 2012. Production of DAPG and HCN by Pseudomonas sp. LBUM3s00 contributes to the biological control of bacterial canker of tomato. Phytopathology, 102: 967-973.

DOI: 10.1094/PHYTO-11-11-0312

Laville, J., C. Blumer, C. Von Schroetter, V. Gaia and G. De Fago et al., 1998. Characterization of the hcnABC gene cluster encoding hydrogen cyanide synthase and anaerobic regulation by ANR in the strictly aerobic biocontrol agent Pseudomonas fuorescens CHA0. J. Bacteriol., 180: 3187-3196.

Long, S.R., 2001. Genes and signals in the rhizobiumlegume symbiosis. Plant Physiol., 125: 69-72. DOI: $10.1104 / p p .125 .1 .69$

Loper, J.E. and M.D. Henkels, 1999. Utilization of heterologous siderophores enhances levels of iron available to Pseudomonas putida in the rhizosphere. Appl. Environ. Microbiol., 65: 5357-5363. PMCID: PMC91729 
Loper, J.E. and H. Gross, 2007. Genomic analysis of antifungal metabolite production by Pseudomonas fluorescens Pf-5. Eur. J. Plant Pathol., 119: 265-278. DOI: $10.1007 / \mathrm{s} 10658-007-9179-8$

Lorck, H., 1948. Production of hydrocyanic acid by bacteria. Physiol. Plantarum, 1: 142-146. DOI: 10.1111/j.1399-3054.1948.tb07118.x

Lugtenberg, B. and F. Kamilova, 2009. Plant-growthpromoting rhizobacteria. Ann. Rev. Microbiol., 63: 541-556.

DOI: 10.1146/annurev.micro.62.081307.162918

Lugtenberg, B.J.J., L. Dekkers and G.V. Bloemberg, 2001. Molecular determinants of rhizosphere colonization by Pseudomonas. Ann. Rev. Phytopathol., 39: 461-490.

DOI: 10.1146/annurev.phyto.39.1.461

Ma, Y., M. Rajkumar and H. Freitas, 2009. Improvement of plant growth and nickel uptake by nickel resistant-plant-growth promoting bacteria. J. Hazard. Mater., 166: 1154-1161.

DOI: $10.1016 /$ j.jhazmat.2008.12.018

Mabood, F., X. Zhou and D.L. Smith, 2014. Microbial signaling and plant growth promotion. Can. J. Plant Sci., 94: 1051-1063. DOI: 10.4141/cjps2013-148

Maggio, A., G. Barbieri, G. Raimondi and S. de Pascale, 2010. Contrasting effects of GA3 treatments on tomato plants exposed to increasing salinity. J. Plant Growth Regul., 29: 63-72.

DOI: $10.1007 / \mathrm{s} 00344-009-9114-7$

Mahdi, S.S., G.I. Hassan, S.A. Samoon, H.A. Rather and S.A. Dar et al., 2010. Biofertilizers in organic agriculture. J. Phytol., 2: 42-54.

Maleki, M., S. Mostafaee, L. Mokhtarnejad and M. Farzaneh, 2010. Characterization of Pseudomonas fluorescens strain CV6 isolated from cucumber rhizosphere in varamin as a potential biocontrol agent. AJCS, 4: 676-683.

Mansour, F.A., H.S. Ildesuguy and H.A. Hamedo, 1994. Studies on plant growth regulator sand enzyme production by some bacteria. Qatar Univ. Sci. J., 14: 81-288.

Markowich, N.A. and G.L. Kononova, 2003. Lytic enzymes of trichoderma and their role in plant defense from fungal diseases: A review. Applied Biochem. Microbiol., 39: 341-351. DOI: $10.1023 / \mathrm{A}: 1024502431592$

Marschner, H., 1995. Mineral Nutrition of Higher Plants. 1st Edn., Academic Press, San Diego, CA.

Mazid, M., T.A. Khan and F. Mohammad, 2012. Role of nitrate reductase in nitrogen fixation under photosynthetic regulation. World J. Pharm. Res., 1: 386-414.

Mazzola, M., D.K. Fujimoto, L.S. Thomashow and R.J. Cook, 1995. Variation in sensitivity of gaeumannomyces graminis to antibiotics produced by Fluorescens pseudomonas sp. and effect on biological control of take-all of wheat. Applied Environ. Microbiol., 61: 2554-2559.
Merchan, F., L. de Lorenzo, S. González-Rizzo, A. Niebel and M. Megías et al., 2007. Analysis of regulatory pathways involved in the reacquisition of root growth after salt stress in Medicago truncatula. Plant J., 51: 1-17. DOI: 10.1111/j.1365-313X.2007.03117.x

Mia, M.A.B., Z.H. Shamsuddin and M. Maziah, 2010. Use of plant growth promoting bacteria in banana: A new insight for sustainable banana production. Int. J. Agric. Biol., 12: 459467.

Miller, M.B. and B.L. Bassler, 2001. Quorum sensing in bacteria. Ann. Rev. Microbiol., 55: 165-199. DOI: 10.1146/annurev.micro.55.1.165

Miller, M.J. and F. Malouin, 1994. SiderophoreMediated Drug Delivery: The Design, Synthesis and Study of Siderophore-Antibiotic and Antifungal Conjugates. In. Microbial Iron Chelates, Bergeron R. (Ed.), Boca Raton, Fla: CRC Press. Pp: 275-306.

Minuto, A., D. Spadaro, A. Garibaldi and M.L. Gullino, 2006. Control of soil borne pathogens of tomato using a commercial formulation of Streptomy cesgriseoviridis and solarization. Crop Prot., 25: 468-475.

Muñoz-Rojas, J. and J. Caballero-Mellado, 2003. Population dynamics of gluconacetobacter diazotrophicus in sugarcane cultivars and its effect on plant growth. Microbial Ecol., 46: 454-464. DOI: $10.1007 / \mathrm{s} 00248-003-0110-3$

Nakkeeran, S., W.G.D. Fernando and Z.A. Siddiqui, 2005. Plant Growth Promoting Rhizobacteria Formulations and Its Scope in Commercialization for the Management of Pests and Diseases. In: PGPR: Biocontrol and Biofertilization, Siddiqui, Z.A. (Ed.), Springer, Dordrecht, The Netherlands, ISBN-10: 978-1-4020-4152-5, pp: 257-296.

Ngumbi, E. and J. Kloepper, 2016. Bacterial-mediated drought tolerance: Current and future prospect. Applied Soil Ecol., 105: 109-125.

DOI: 10.1016/j.apsoil.2016.04.009

Niranjan, R., H.S. Shetty and M.S. Reddy, 2005. Plant Growth-Promoting Rhizobacteria: Potential Green Alternative for Plant Productivity. In: PGPR: Biocontrol And Biofertilization, Siddiqui, Z.A. (Ed.), Springer, Dordrecht, pp: 197-216.

Nisha, K., S.N.P. Devi, S. Vasandha and K.K. Sunitha, 2014. Role of phosphorous solubilizing microorganisms to eradicate $\mathrm{P}$ deficiency in plants: A review. Int. J. Sci. Res. Pub., 4: 1-5.

Noordman, W.H., R. Reissbrodt, R.S. Bongers, I.L.W. Rademaker and W. Bockelmann et al., 2006. Growth stimulation of Brevibacterium sp. by siderophores. J. Applied Microbiol., 101: 637-646.

Normanly, J., 1997. Auxin metabolism. Physiol. Plantarum, 100: 431-442. 
Noumavo, P.A., N.A. Agbodjato, F. Baba-Moussa, A. Adjanohoun and L. Baba-Moussa, 2016. Plant growth promoting rhizobacteria: Beneficial effects for healthy and sustainable agriculture. Afr. J. Biotech., 15: 1452-1463.

Odoh, C.K., 2017. Plant Growth Promoting Rhizobacterial (PGPR): A bioprotectant bioinoculant for sustainable agrobiology. Int. J. Adv. Res. Biol. Sci., 4: 123-142. DOI: 10.22192/ijarbs.2017.04.05.014

Odoh, C.K., U.K. Akpi and F. Anya, 2017a. Environmental impact of mineral exploration in Nigeria and their phytoremediation strategies for sustainable ecosystem. Global J. Sci. Front. Res., 17: 19-27.

Odoh, C. K., P.E. Martins, U.K. Akpi, U. Okekeaji and U.S. Adobu, 2017b. Phytoremediation potential of Vigna unguiculata on lead polluted soil and its biotoxic effects on soil microbial activities. Global J. Sci. Front. Res., 17: 35-42.

Palumbo, J.D., G.Y. Yuen, C.C. Jochum, K.Tatum and D.Y. Kobayashi, 2005. Mutagenesis of beta 1, 3glucanase genes in Lysobacter enzymogenes strain $\mathrm{C} 3$ results in reduced biological control activity toward Bipolaris leaf spot of tall fescue and Pythium damping-off of sugar beet. Phytopathology, 95: 701-707.

Patten, C.L. and B.R.Glick, 2002. Role of Pseudomonas putida indole acetic acid in development of the host plant root system. Applied Environ. Microbiol., 68: 3795-3801.

Pérez-Montano, F., C. Alías-Villegas, R.A. Bellogín, P. del Cerro and M.R. Espuny et al., 2014. Plant growth promotion in cereal and leguminous agricultural important plants: From microorganism capacities to crop production. Microbiol. Res., 169: 325-336. DOI: 10.1016/j.micres.2013.09.011

Perneel, M., L. D'hont, K. De, Maeyer, A. Adiobo and K. Rabaey et al., 2008. Phenazines and biosurfactants interact in the biological control of soil-borne diseases caused by Pythium spp. Environ. Microbiol., 10: 778-788.

Perret, X., C. Staehelin and W.J. Broughton, 2000. Molecular basis of symbiotic promiscuity. Microbiol. Mol. Biol. Rev., 64: 180-201. PMCID: PMC98991

Perrott, K.W., S.U. Sarathchandra and B.W. Dow, 1992. Seasonal and fertilizer effects on the organic cycle and microbial biomass in a hill country soil under pasture. Aust. J. Soil Res., 30: 383-394.

DOI: $10.1071 /$ SR9920383

Persello-Cartieaux, F., L. Nussaume and C. Robaglia, 2003. Tales from the underground: Molecular plantrhizobacteria interactions. Plant Cell Environ., 26: 189-199. DOI: $10.1064 /$ j.1365-3040.2003.00956.x
Petersen, S.O. and M.J. Klug, 1994. Effects of sieving, storage and incubation temperature on the phospholipid fatty acid profile of a soil microbial community. Appl. Environ. Microbiol., 60: 2421-2430.

Pierik, R., D. Tholen, H. Poorter, E.J. Visser and L.A. Voesenek, 2006. The Janus face of ethylene: Growth inhibition and stimulation. Trends Plant Sci., 11: 176-183. DOI: 10.1016/j.tplants.2006.02.006

Pieterse, C.M., C. Zamioudis, R.L. Berendsen, D.M. Weller and S.C. VanWees et al., 2014. Induced systemic resistance by beneficial microbes. Ann. Rev. Phytopathol., 52: 347-375.

DOI: 10.1146/annurev-phyto-082712-102340

Pliego, C., F. Kamilova and B. Lugtenberg, 2011. Plant Growth-Promoting Bacteria: Fundamentals and exploitation In: Bacteria in Agrobiology Crop Ecosystems, Maheshwari, D.K. (Ed.), Springer, Heidelberg, pp: 295-343.

Podile, A.R. and G.K. Kishore, 2006. Plant growthPromoting Rhizobacteria. In: Plant-Associated Bacteria, Gnanamanickam, S.S. (Ed.), Springer, The Netherlands, ISBN-10: 978-1-4020-4538-7, pp: 195-230.

Pospísilová, J., 2003a. Interaction of cytokinins and abscisic acid during regulation of stomatal opening in bean leaves. Photosynthetica, 41: 49-56.

Pospíšilová, J., 2003b. Participation of phytohormones in the stomatal regulation of gas exchange during water stress. Biol. Plantarum, 46: 491-506.

Prapagdee, B., C. Kuekulvong and S. Mongkolsuk, 2008. Antifungal potential of extracellular metabolites produced by Streptomyces hygroscopicus against phytopathogenic fungi. Int. J. Biol. Sci., 4: 330-337. DOI: 10.7150/ijbs.4.330

Qurashi, A.W. and A.N. Sabri, 2012. Bacterial exopolysaccharide and biofilm formation stimulate chickpea growth and soil aggregateon under salt stress. Braz. J. Microbiol., 43: 1183-1191. DOI: $10.1590 / \mathrm{S} 1517-838220120003000046$

Raaijmakers, J., I. De Bruin, O. Nybroe and M. Ongena, 2010. Natural functions of cyclic lipopeptides from $\mathrm{Ba}$ cillusand Ps eudomona s: More than surfactants and antibiotics. FEMS Microbiol. Rev., 34: 1037-1062. DOI: $10.1111 /$ j.1574 6976.2010.00221.x

Radzki, W., F.J.G. Manero, E. Algar, J.A. Lucas García and A. García-Villaraco et al., 2013. Bacterial siderophores efficiently provide iron to iron-starved tomato plants in hydroponics culture. Antonie Van Leeuwenhoek, 104: 321-330. DOI: $10.1007 / \mathrm{s} 10482-013-9954-9$

Ramachandran, K., V. Srinivasan, S. Hamza and M. Anadaraj, 2007. Phosphate solubilizing bacteria isolated from the rhizosphere soil and its growth promotion on black pepper (Piper nigrum L.) cutting. Plant Soil Sci., 102: 325-331. 
Reinhold-Hurek, B. and T. Hurek, 1998. Interactions of gramineous plants with Azoarcus spp. and other diazotrophs: Identification, localization and perspectives to study their function. Crit. Rev. Plant Sci., 17: 29-54.

Richardson, A.E. and R.J. Simpson, 2011. Soil microorganisms mediating phosphorus availability. Plant Physiol.,156: 989-996. DOI: $10.1104 /$ pp.111.175448

Roberts, N.J., G. Morieri, G. Kalsi, A. Rose and J. Stiller et al., 2013. Rhizobial and mycorrhizal symbioses in Lotus japonicus require lectin nucleotide phosphohydrolase, which acts upstream of calcium signaling. Plant Physiol., 161: 556-567.

Robin, A., G. Vansuyt, P. Hinsinger, J.M. Meyer and J.F. Briat et al., 2008. Iron dynamics in the rhizosphere: Consequences for plant health and nutrition. Adv. Agron., 99: 183-225.

Rodriguez, H. and R. Fraga, 1999. Phosphate solubilizing bacteria and their role in plant growth promotion. Biotech. Adv., 17: 319-339. PMID: 14538133

Ryals, J.A., U.H. Neuenschwander, M.G. Willits, A. Molina and H.Y. Steiner et al., 1996. Systemic acquired resistance. Plant Cell, 8: 1809-1819. DOI: $10.1105 /$ tpc.8.10.1809

Sabry, S.R.S., S.A. Saleh, C.A. Batchelor, J. JQones and J. Jotham et al., 1997. Endophytic establishment of Azorhizobium caulinodans in wheat. Procee. Biol. Sci., 264: 341-346. DOI: 10.1098/rspb.1997.0049.

Sagervanshi, A., P. Kumari, A. Nagee and A. Kumar, 2012. Isolation and characterization of phosphate solublizing bacteria from anand agriculture soil. Int. J. Life Sci. Pharma. Res., 23: 256-266.

Saharan, B.S. and V. Nehra, 2011. Plant growth promoting rhizobacteria: A critical review. Life Sci. Med. Res., 21: 1-30.

Sandhya, V., S.Z. Ali, B. Venkateswarlu, G. Reddy and M. Grover, 2010. Effect of osmotic stress on plant growth promoting Pseudomonas spp. Arch. Microbiol., 192: 867-76.

DOI: $10.1007 / \mathrm{s} 00203-010-0613-5$

Sandy, M. and A. Butler, 2009. Microbial iron acquisition: Marine and terrestrial siderophores. Chem Rev., 109: 4580-4595.

Saraf, M., C.K. Jha and D. Patel, 2011. The Role of ACC Deaminase Producing PGPR in Sustainable Agriculture. In: Plant Growth and Health Promoting Bacteria Microbiology, Monographs, Maheshwari, D.K. (Ed.), Springer, Germany, pp: 365-386.

Schoenborn, L., P.S. Yates, B.E. Grinton, P. Hugenholtz and P.H. Janssen, 2004. Liquid serial dilution is inferior to solid media for isolation of cultures representative of the phylum-level diversity of soil bacteria. Applied Environ. Microbiol., 70: 4363-4366. DOI: 10.1128/AEM.70.7.4363-4366.2004
Schultze, M. and A. Kondorosi, 1998. Regulation of symbiotic root nodule development. Ann. Rev. Genet., 32: 33-57. DOI: 10.1146/annurev.genet.32.1.33

Sheng, X.F., J.J. Xia, C.Y. Jiang, L.Y. He and M. Qian, 2008. Characterization of heavy metal-resistant endophytic bacteria from rape (Brassica napus) roots and their potential in promoting the growth and lead accumulation of rape. Environ. Pollut., 156: 1164-1170. DOI: 10.1016/j.envpol.2008.04.007

Shobha, G. and B.S. Kumudini, 2012. Antagonistic effect of the newly isolated PGPR Bacillus spp. on Fusarium oxysporum. Int. J. Applied Sci. Eng. Res., 1: 463-474.

Shuhegger, R., A. Ihring, S. Gantner, G. Bahnweg and C. Knaooe et al., 2006. Induction of systemic resistance in tomato plants by N-acyl-L-homoserine lactone producing rhizosphere bacteria. Plant Cell Environ., 29: 909-918. PMID: 17087474

Sieberer, B.J., M. Chabaud, A.C. Timmers, A. Monin and J. Fournier et al., 2009. A nuclear-targeted cameleon demonstrates intranuclear $\mathrm{Ca}^{2+}$ spiking in Medicago truncatula root hairs in response to rhizobial nodulation factors. Plant Physiol., 151: 1197-1206.

Silo-Suh, L.A., B.J. Lethbridge, S.J. Raffel, H. He and J. Clardy et al., 1994. Biological activities of two fungistatic antibiotics produced by bacillus cereus UW85. Applied Environ. Microbiol., 60: 2023-2030.

Simonet, P., P. Normand and A. Moiroud, 1990. Identification of frankia strains in nodules by hybridization of polymerase chain reaction products with strain-specific oligonucleotide probes. Arch. Microbiol., 153: 235-240.

DOI: $10.1007 / \mathrm{BF} 00249074$

Singh, I.P, J. Sidana, S.B. Bharate and W.J. Fole, 2010. Phloroglucinol compounds of natural origin: Synthetic aspects. Nat Prod. Rep., 27: 393-416.

Sivasakthi, S., G. Usharani and P. Saranraj, 2014. Biocontrol potentiality of Plant Growth Promoting Bacteria (PGPR)-Pseudomonas fluorescens and Bacillus subtilis: A review. Afr. J. Agri. Res., 9: 1265-1277. DOI:10.1007/BF00249074

Sokolova, M.G., G.P. Akimova and O.B. Vaishlia, 2011. Effect of phytohormones synthesized by rhizosphere bacteria on plants. Prikladnaia Biokhimiia Mikrobiol., 47: 302-307. DOI: 10.1134/S0003683811030148

Somers, E., I. Vanderleyden and M. Srinivasan, 2004. Rhizosphere bacterial signalling: A love parade beneath our feet. Crit. Rev. Microbiol., 30: 205-240.

Spaink, H.P., 2000. Root nodulation and infection factors produced by rhizobial bacteria. Ann. Rev. Microbiol., 54: 257-288.

DOI: 10.1146/annurev.micro.54.1.257 
Steinshamn, H., E. Thuen, M.A. Bleken, U.T. Brenoe and G. Ekerholt et al., 2004. Utilization of Nitrogen (N) and Phosphorus $(\mathrm{P})$ in an organic dairy farming system in Norway. Agri. Ecosys. Environ., 104: 509-522.

Sundara, B., V. Natarajan and K. Hari, 2002. Influence of phosphorus solubilizing bacteria on the changes in soil available phosphorus and sugarcane and sugar yield. Field Crop Res., 77: 43-49.

DOI: $10.1016 / \mathrm{S} 0378-4290(02) 00048-5$

Sureshbabu, K., N. Amaresan and K. Kumar, 2016. Amazing multiple function properties of plant growth promoting rhizobacteria in the rhizosphere soil. Int. J. Cur. Microbiol. Applied Sci., 5: 661683. DOI: 10.20546/ijcmas.2016.502.074

Thamer, S., M. Schädler, D. Bonte and D. J. Ballhorn, 2011. Dual benefit from a belowground symbiosis: Nitrogen fixing rhizobia promote growth and defense against a specialist herbivore in a cyanogenic plant. Plant Soil, 341: 209-219.

DOI: $10.1007 / \mathrm{s} 11104-010-0635-4$

Tian, F., Y. Ding, H. Zhu, L. Yao and B. Du, 2009. Genetic diversity of siderophore-producing bacteria of tobacco rhizosphere. Braz J. Microbiol., 40: 276-284. DOI: 10.1590/S1517-838220090002000013

Tilak, K.V.B.R., N. Ranganayaki, K.K. Pal, R. De and A.K. Saxena et al., 2005. Diversity of plant growth and soil health supporting bacteria. Cur. Sci., 89: 136-150.

Tilman, D., 1998. The greening of the green revolution. Nature, 396: 211-212. DOI : 10.1038/24254

Timmusk, S., V. Paalme, T. Pavlicek, J. Bergquist and A. Vangala et al., 2011. Bacterial distribution in the rhizosphere of wild barley under contrasting microclimates. PLoS One, 6: 1-7.

DOI: 10.1371/journal.pone.0017968

Van der Helm, D. and G. Winkelmann, 1994. Hydroxamates and Polycarbonates as Iron Transport Agents (Siderophores) in Fungi. In: Metal ions in Fungi, Winkelmann, G. and D.R. Winge (Eds.), New York, Pp: 39-148.

Van Loon, L.C., 2007. Plant responses to plant growthpromoting rhizobacteria. Eur. J. Plant Pathol., 119: 243-254. DOI: 10.1007/s10658-007-9165-1

Van-Veen, J.A., L.S. Van Overbeek and J.D. Van Elsas, 1997. Fate and activity of microorganisms introduced into soil. Microbiol. Mol. Biol. Rev., 61: 121-135. DOI: 1092-2172/97/\$04.0010

Vazquez, P., G. Holguin, M.E. Puente, A. Lopez-Cortes and Y. Bashan, 2000. Phosphate-solubilizing microorganisms associated with the rhizosphere of mangroves in a semiarid coastal lagoon. Biol. Fertil. Soils, 30: 460-468. DOI: 10.1007/s003740050024
Verma, V.C., S.K. Singh and S. Prakash, 2011. Biocontrol and plant growth promotion potential of siderophore producing endophytic Streptomyces from Azadirachta indica A. Juss. J. Basic Microbiol., 51: 550-556. DOI: $10.1002 /$ jobm.201000155

Vessey, J.K., 2003. Plant growth promoting rhizobacteria as biofertilizers. Plant Soil, 255: 571-586. DOI: 10.1023/A:1026037216893

Vettakkorumakankav, N.N., D. Falk, P. Saxena and R.A. Fletcher, 1999. Crucial role for gibberellin in stress protecting of plants. Plant Cell Physiol., 40: 542-548. DOI: 10.1093/oxfordjournals.pcp.a029575

Vikram, A. and H. Hamzehzarghani, 2008. Effect of phosphate solubilizing bacteria on nodulation and growth parameters of greengram (Vignaadiate L. Wilczek). Res. J. Microbiol., 3: 62-72. DOI: $10.3923 / \mathrm{jm} .2008 .62 .72$

Vivas, A., B. Biru, J.M. Ruiz-Lozano and R. Azcon, 2006. Two bacterial strains isolated from $\mathrm{Zn}$ polluted soil enhance plant growth and micorrhizal efficiency under $\mathrm{Zn}$ toxicity. Chemosphere, 52: 1523-1533.

Voisard, C., C. Keel, D. Haas and G. Defago, 1989. Cyanide production by Pseudomonas fluorescens helps supc conditions. EMBO J., 8: 351-358. PMID: 16453871

Wan, M., G. Li, J. Zhang, D. Jiang and H.C. Huang, 2008. Effect of volatile substances of Streptomyces platensis F-1 on control of plant fungal diseases. Biol. Control, 46: 552-559.

Wang, Y, S.E. Kern and D.K. Newman, 2010. Endogenous phenazine antibiotics promote anaerobic survival of Pseudomonas aeruginosa via extracellular electron transfer. J Bacteriol. 192: 365-369.

Wani, S.A., S. Chand and T. Ali, 2013. Potential use of azotobacter chroococcum in crop production: An overview. Cur. Agri. Res. J., 1: 35-38.

DOI: 10.12944/CARJ.1.1.04

Weyens, N., S. Truyens, J. Dupae, L. Newman and S. et al., 2010. Potential of the TCE-degrading endophyte Pseudomonas putida W619-TCE to improve plant growth and reduce TCE phytotoxicity and evapotranspiration in poplar cuttings. Environ Poll., 158: $2915-2919$.

DOI: $10.1016 /$ j.envpol.2010.06.004

Yamaguchi, S., 2008. Gibberellin metabolism and its regulation. Ann. Rev. Plant Biol., 59: 225-251. DOI: 10.1146/annurev.arplant.59.032607.092804

Yasari, E. and A.M. Patwardhan, 2007. Effects of (Aztobacter and Azospirillium) inoculations and chemical fertilizers on growth and productivity of Canola (Brassica napus L). Asian J. Plant Sci., 6: 77-82. 
Yaxley, J.R., J.J Ross, L.J. Sherriff and J.B. Reid, 2001. Gibberellin biosynthesis mutations and root development in pea. Plant Physiol.,125: 627-633. DOI: $10.1104 /$ pp.125.2.627

Yazdani, M., M.A. Bahmanyar, H. Pirdashti and M.A. Esmaili, 2009. Effect of Phosphate Solubilization Microorganisms (PSM) and Plant Growth Promoting Rhizobacteria (PGPR) on yield and yield components of Corn (Zea mays L.). Proc. World Acad. Sci. Eng. Tech., 37: 90-92.

Young, J.P.W. and K.E. Haukka, 1996. Diversity and phylogeny of rhizobia. New Phytol., 133: 87-94.

Zahir, Z.A., M.K. Shah, M. Naveed and M.J. Akhtar, 2010. Substrate dependent auxin production by Rhizobium phaseoli improves the growth and yield of Vigna radiate L. under salt stress conditions. J. Microbiol. Biotech., 20: 1288-1294. PMID: 20890093
Zahran, H. and H., 2001. Rhizobia from wild legumes: Diversity, taxonomy, ecology, nitrogen fixation and biotechnology. J. Biotech., 91: 143-153. DOI: 10.1016/S0168-1656(01)00342-X

Zaidi, A., M.S. Khan, M. Ahemad, M. Oves and P.A. Wani, 2009. Recent Advances in Plant Growth Promotion by Phosphate-Solubilizing Microbes. In: Microbial Strategies for Crop Improvement, Khan M.S. (Ed.), Berlin Heidelberg: SpringerVerlag, pp: 23-50.

Zehnder, G.W., J.F. Murphy, E.J. Sikora and J.W. Kloepper, 2001. Application of rhizobacteria for induced resistance. Euro. J. Plant Pathol., 107: 39-50. DOI:10.1023/A:1008732400383

Zhuang, X., J. Chen, H. Shim and Z. Bai, 2007. New advances in plant growth-promoting rhizobacteria for bioremediation. Environ. Int., 33: 406-413. DOI: 10.1016/j.envint.2006.12.005 